\title{
فاعلية البرامج التدريبية في تلبية احتياجات أعضاء هيئة التدريس دراسة مطبقة على أعضاء هيئة الثدريس في جامعة الأميرة نورة بنت عبد الرحمن
}

\author{
إعداد
}

$$
\begin{aligned}
& \text { د. بلرية سليمان محمد العمرو } \\
& \text { أستاذ التخطيط الاجتماعي المساعد } \\
& \text { قسم التخطيط الاجتماعي } \\
& \text { كلية الخدمة الاجتماعية } \\
& \text { جامعة الأميرة نورة بنت عبد الرحمن الاحنياعة }
\end{aligned}
$$

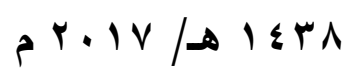




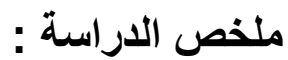

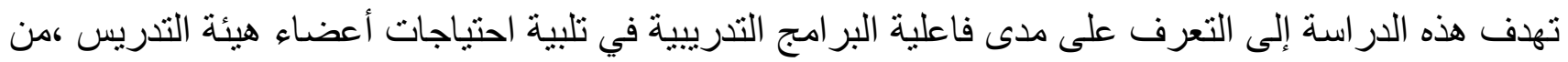

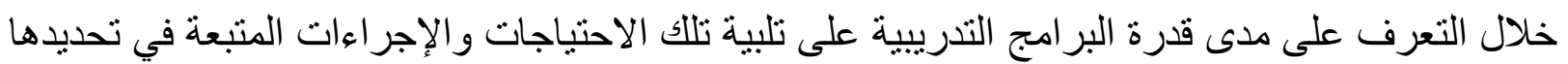

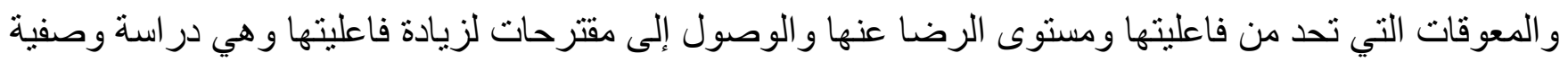

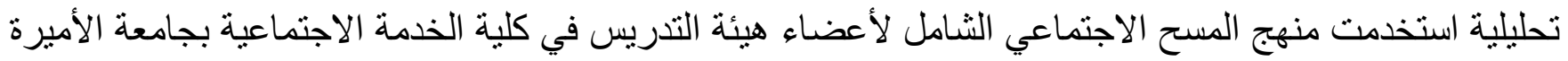

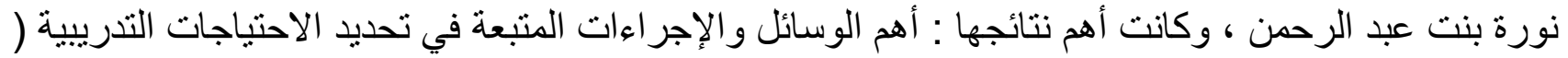

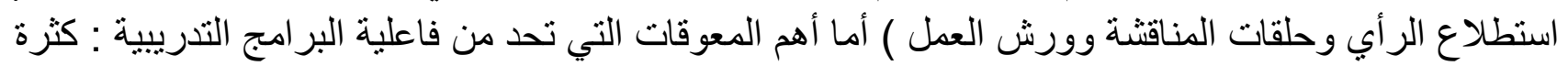

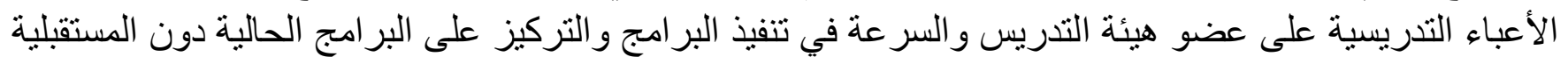

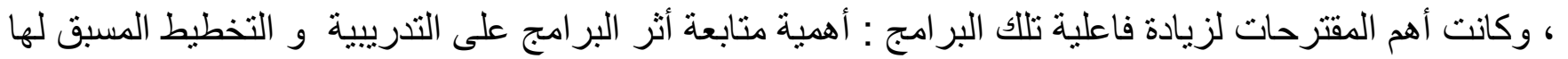

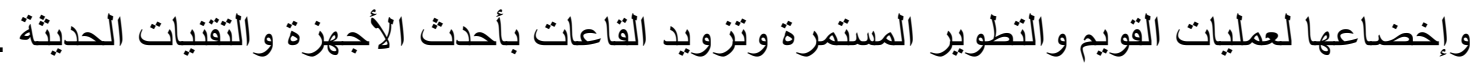

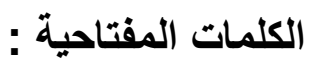

البر امج التنديبية ، الفاعلية ، عضو هيئة التنديس ، الاحتياجات

The objective of this study is to identify the training programs effectiveness in meeting the needs of faculty members by identifying the extent of the training programs abilities to meet these needs and the procedures followed in determining them, the obstacles that limit their effectiveness and level of satisfaction, and to reach proposals for increasing their efficiency. The methodology of the Social Survey was used for faculty members at the Social Service faculty at Princess Noura Bint Abdul Rahman University. The most important results were the most important methods and procedures used in determining the training needs. The most important obstacles of the training programs effectiveness are: the high teaching burdens on the faculty member and the speed in implementing the programs and focusing on the current programs without the future. The most important suggestions for increasing the these programs effectiveness were: The importance of following up the impact of the programs on the training and planning ahead of them and subject them to proper operations and continuous development and provide the halls with the latest equipment and modern technology. 


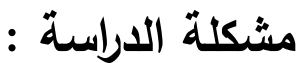

يعتبر تحديد الاحتياجات التدريبية بمثابة القواعد الخراسانية التي تبنى عليها أركان وجدران المنظومة

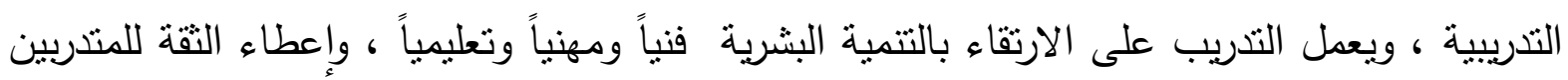

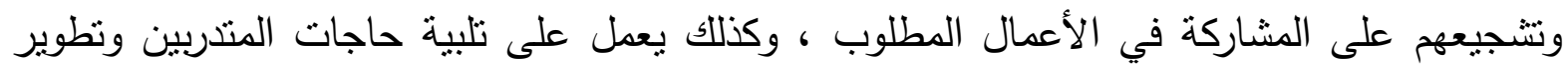

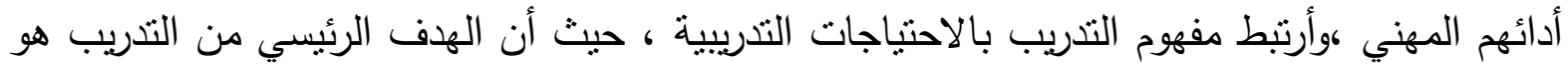

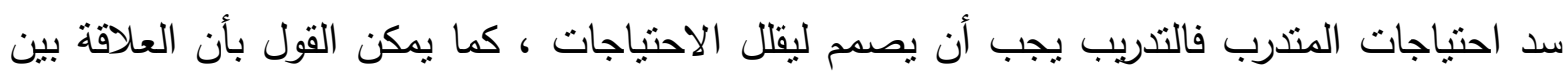

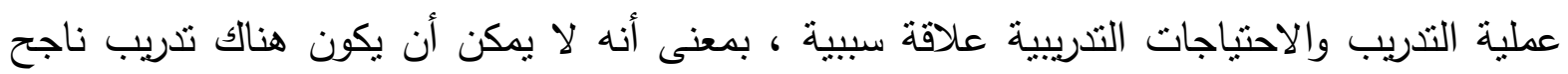
وفعال إلا إذا سبقه تحديد وتقدير للاحتياجات التدريبية. وتحديد الاحتياجات يجعلنا نستطيع أن نحدد نوع ومستوى التدريب المطلوب وتحديد الأفراد الذين يحتاجون للنتريب ومحتوى البرنامج التدريبي والذي يمكنهم من أداء عملهم بكفاءة. إن عدم وجود تحديد للاحتياجات التدريبية بشكل واقعي ودقيق نسبيا يمكن أن يجعل الفعاليات التدريبية

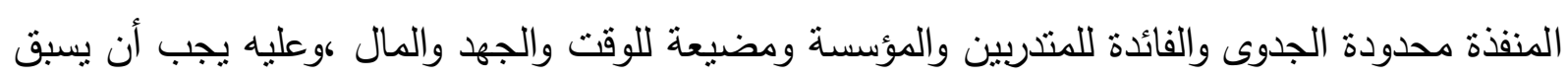

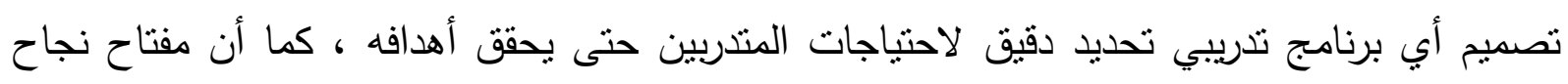

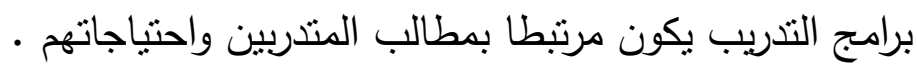

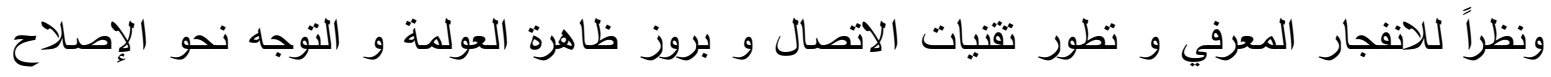
التعليمي وتطور الدراسات والأبحاث في الحقل التربوي فقد بات من الضروري إعداد هيئات تدريسية قادرة على التكيف مع هذه التحديات و المتغيرات، لاسيما و أن إدارات الجامعات أصبحت تدرك بأن مستوى بأن فعالية أداء أعضاء الهيئات التدريسية لا يرتبط فقط بالكادر الأكاديمي فحسب و وإنما بسمعة الجامعات

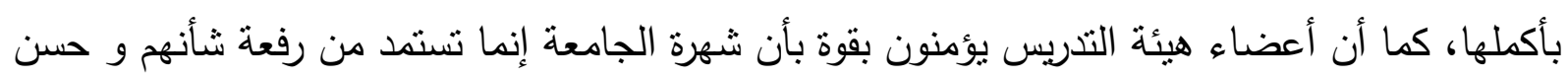

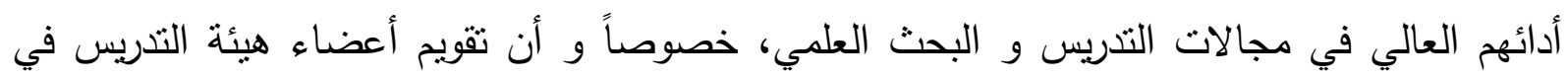
أغلب الجامعات يركز على ثلاثة مجالات رئيسة هي التدريس، والإنتاج العلمي، والأداء في الأنشطة الأخرى داخل و خارج الجامعة. ( المخلافي ، 117،2002).

ويعتبر عضو هيئة التنريس العنصر الفعال في مؤسسات التعليم العالي ، لأنه أحد المدخلات الأساسية في المنظومة التربوية ، وهو الركيزة الأساسية التي يتوقف عليها تحقيق الأهداف التعليمية الجامعية ، بل إن دور الجامعات ومكانتها وسمعتها ترتبط بمكانة أساتنتها وقدرتهم على نأدية أدوارهم الأكاديمية والمهنية ، كيف لا وهم المنوط بهم إعداد وتدريب الطاقة البشرية وإعداد الأبحاث العلمية وحل المشكلات التي تتعرض لها مجتمعاتهم والعمل على خدمنها (عبد الغفار ، 2006، 150) 
ولذلك فإن تهيئة جميع فرص النمو لأعضاء هيئة التدريس ومشاركتهم في عملية صنع القرار ومنحهم

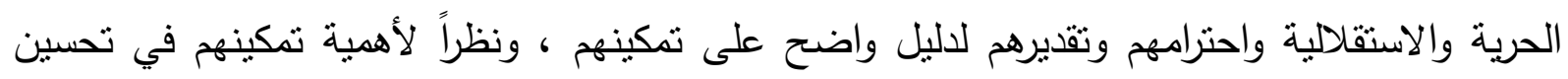

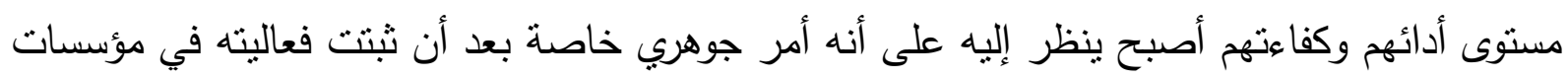
إدارة الأعمال(Mountjoy,2006,41) لقد برزت الحاجة لتدريب أعضاء هيئة التنريس لتطوير مهاراتهم ، وازدادت الحاجة مع الأخذ بتطبيق مفهوم جودة النوعية في التعليم، وقد شعرت الدول المتقدمة بأهمية النطوير المهني لعضو هيئة التنريس ، فأخذت به جامعات بريطانيا وأمريكا وبعض الدول الأوروبية في منتصف القرن الماضي، كما شعرت بالحاجة له مختلف الدول النامية لاسيما في وطننا العربي وذلك في مرحلة ما بعد السبعينات ، فأخذت به به بهاه جامعات عربية في كل من مصر ودول الخليج العربي والعراق والأردن والجزائر ـ(ثاهين ،2004 ، من هنا فإن النطوير المهني لأعضاء هيئة التنريس لم يكن فقط استجابة لنوايا شخصية بقدر ما كان

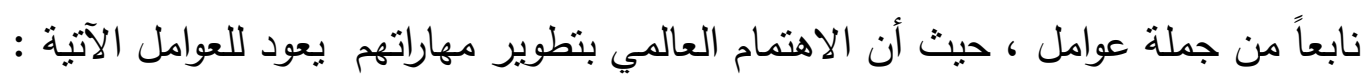

- النطور التكنولوجي و انعكاساته على العملية التعليمية من حيث توظيف تكنولوجيا المعلومات والاتصال وتقنيات التعلم والتعليم فقد أثرت بشكل جذري على الثى نظم التعليم وأساليبه مما تطلب مساعدة

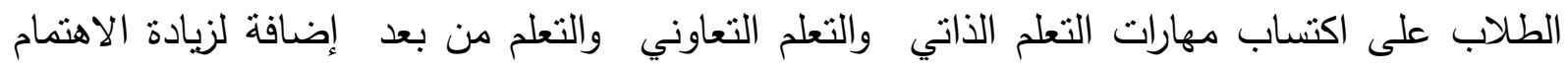

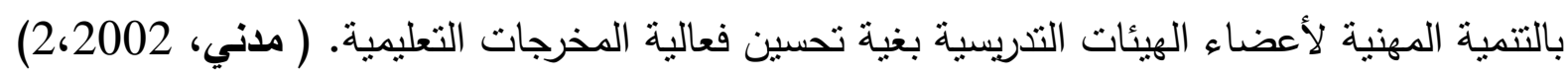

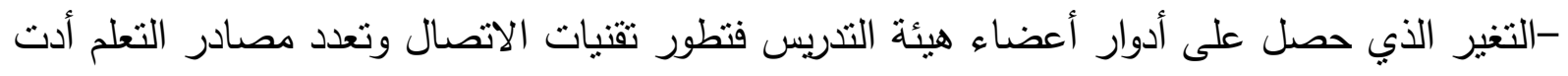

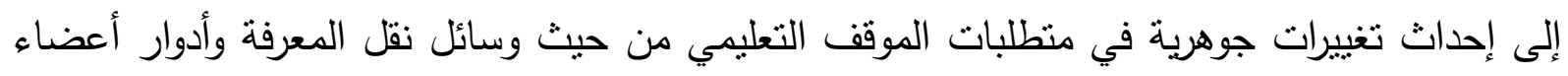
هيئة التدريس التي تحولت من الأدوار التقليدية التي تعتبر المدرس مجرد ناقل للمعرفة إلى القيام بأدوار

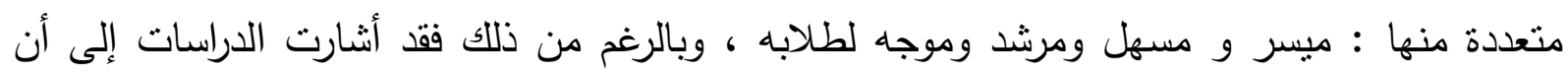

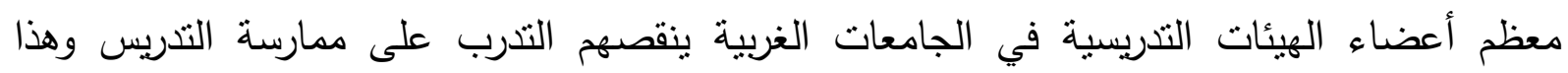

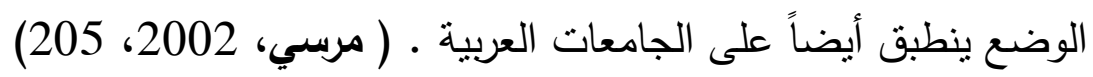

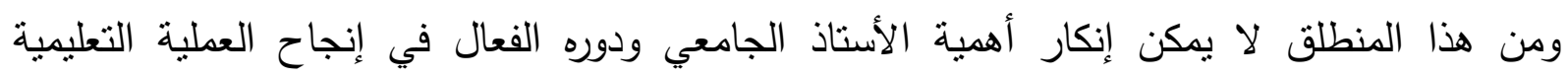

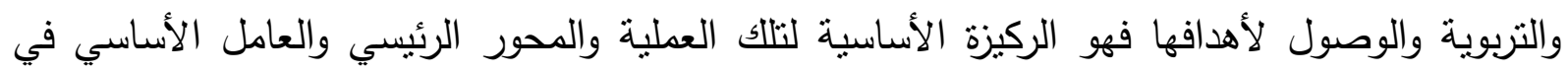

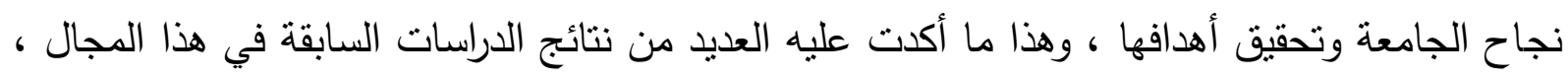

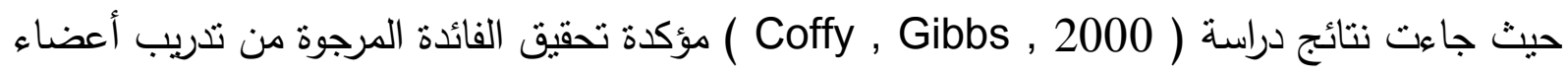

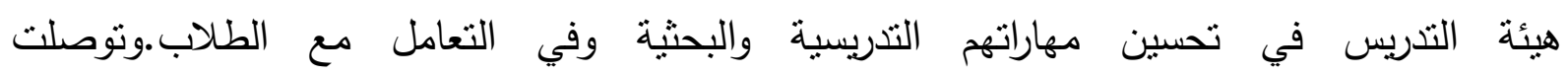
دراسة(Kdlinski,2002) إلى وجود معوقات تواجه مؤسسات التعليم عند نطبيق إدارة الجودة الثشاملة

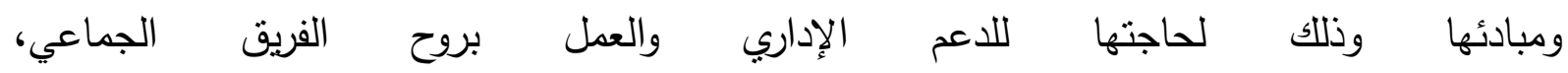


وحددت دراسة (إبراهيم،2003)معايير جودة عضو هيئة التدريس ومنها :اتصافه بالكفاءة في التدريس ونموه المهني المتمنل في مجال البحث العلمي والإنتاج الأكاديمي وخدمة المجتمع والتقويم الدوري بهدف

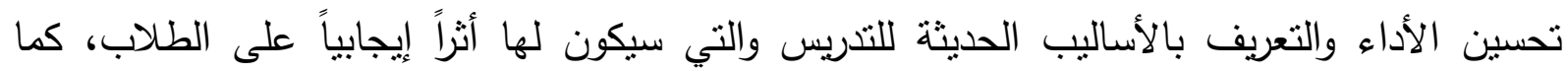
حدت دراسة (Willmer,2003) أساليب تقويم جودة التعليم من قبل أعضاء الهيئة التبريسية في الجامعة وكذلك أهمية التغذية الراجعة المقدمة من قبل الطلاب للدلالة عن مدى جودة طرائق التدريس المتبعة معهم وجودة التعليم ومعاييره ، وأوصت دراسة ( الثربيني ،2004) بإنثاء مركز لنتمية وتطوير لهنه

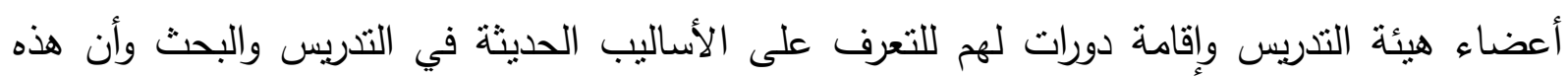

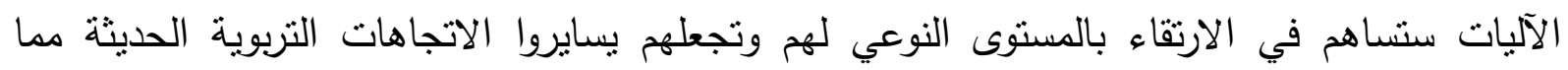

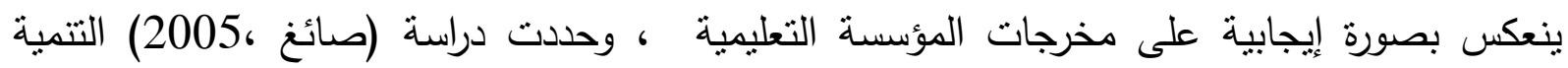

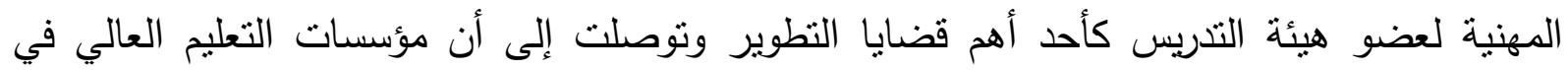

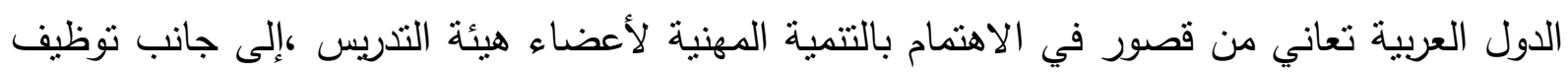

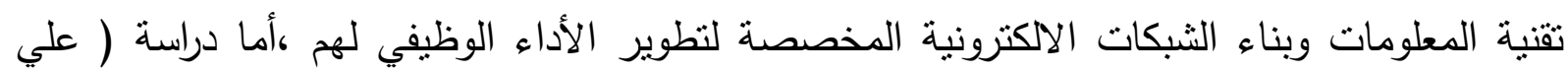

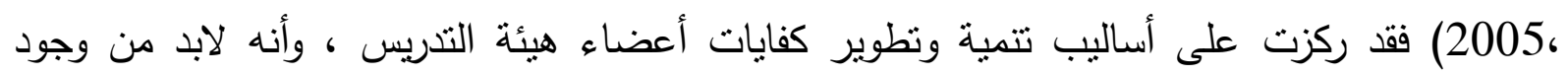

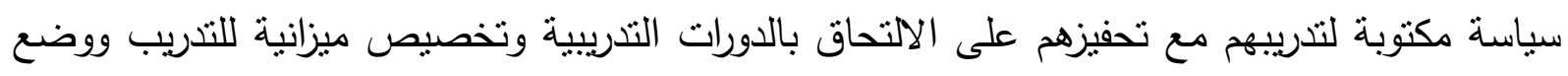

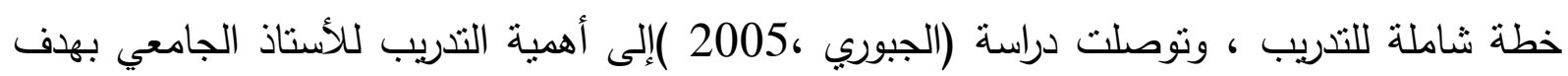
تمكينه من مواجهة التحديات الاستراتيجية في نظم التعليم وأهمية إيجاد صيخ جديدة لتحفيز عضو التهبة هيئة التدريس على تحسين أدائه مع توفير التدريب المناسب على استخدام الحاسب الآلي ووسائل الاتصال

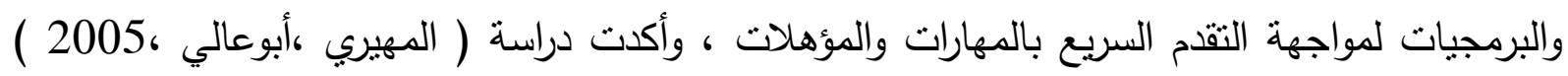

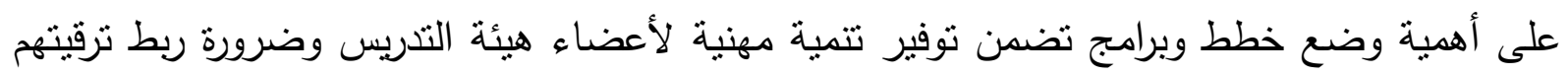

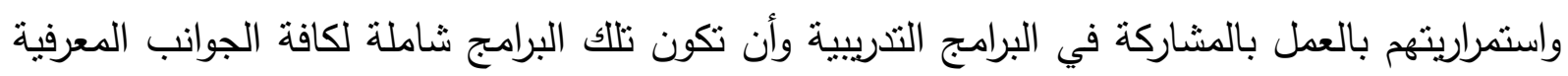

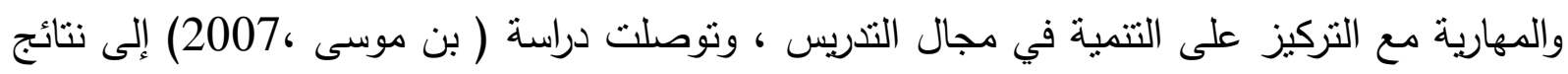

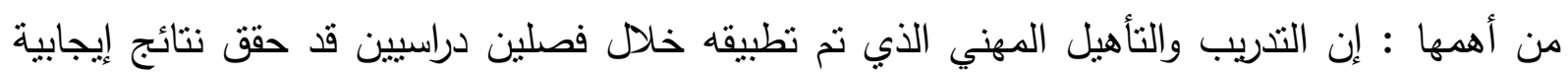

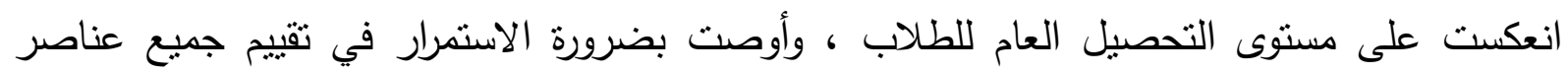

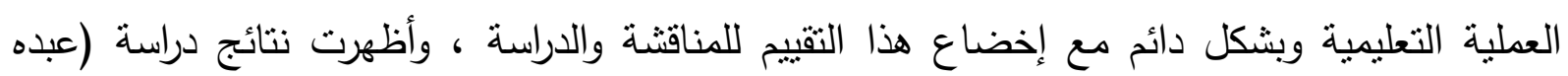

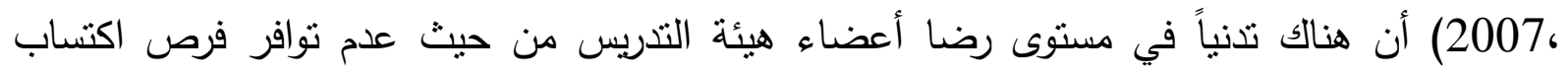

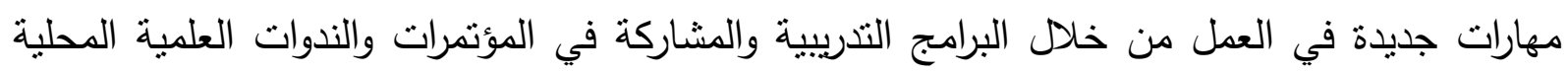
والخارجية ، وأوصت دراسة (التركي ، 2009 ) بضرورة تصميم برامج تدريبية لأعضاء هيئة التدريس في ولني

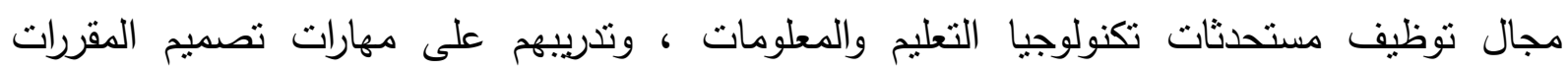

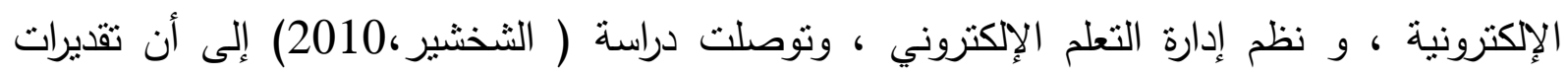

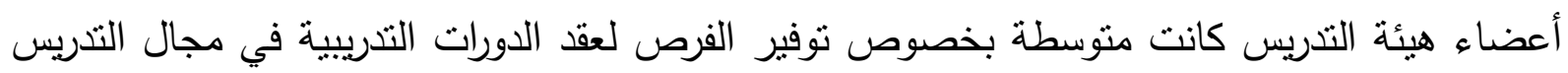


والمشاركة في الندوات والمؤتمرات العلمية المتخصصة ، وذكرت دراسة ( السراج ،2010) أن هناك

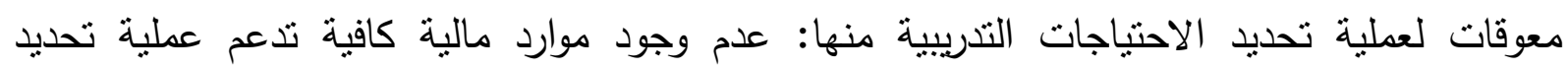
الاحتياجات التنريبية وعدم وجود خطط واضحة لتحديدها وعدم وجود نظام بشكل منتظم لتحديدها وعدم التحديد الدقيق لمعايير الأداء النموذجي للعاملين بالمنظمة وعدم توفر الوقت الكافي وافي لدى القائمين على واتى

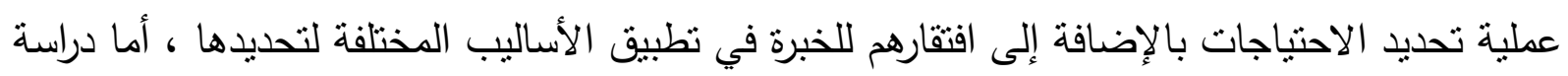

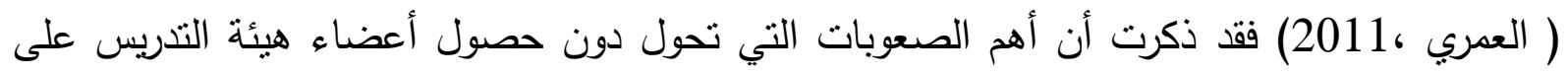

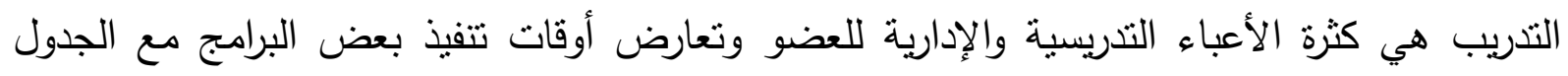

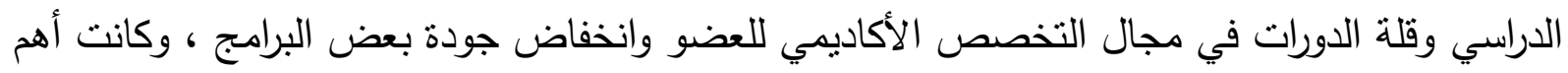
مقترحات الأعضاء حول التدريب المناسب الذي يرغبون في الحصول عليه هو ربط الندريب بالحاجات

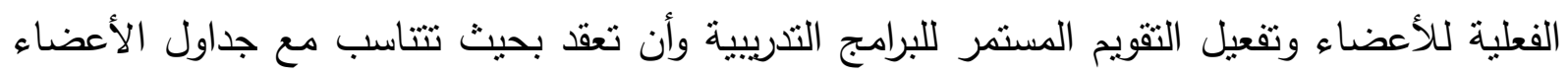

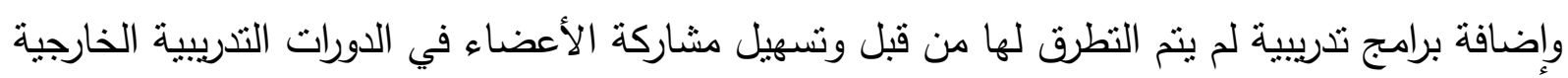

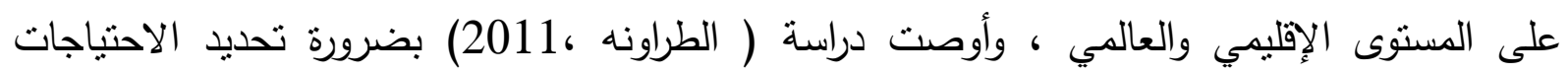
التدريبية واعتبارها الأساس في التخطيط للندريب منعاً للارتجال والعشوائية في طرح البرامج التدريبية

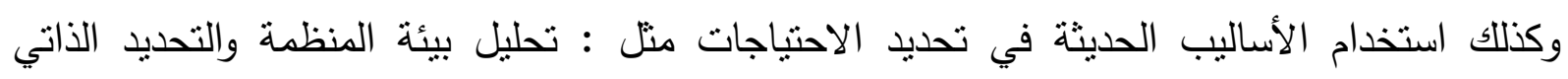

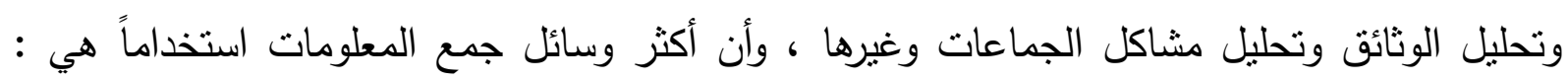

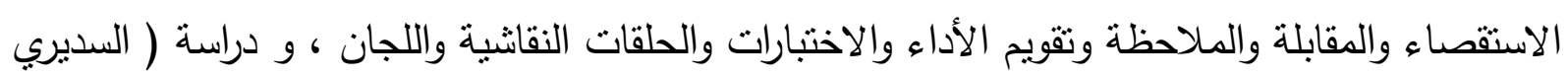

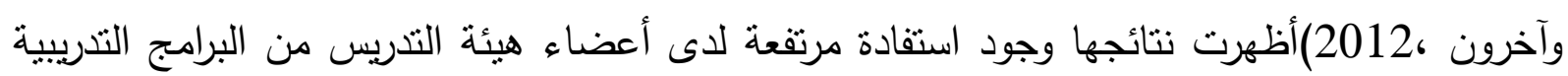

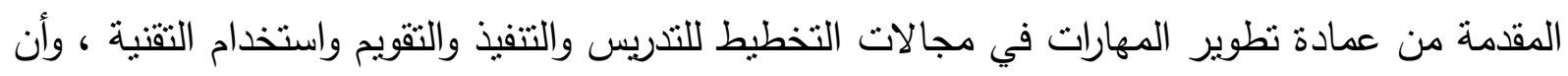

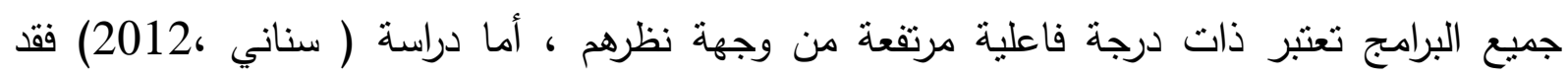

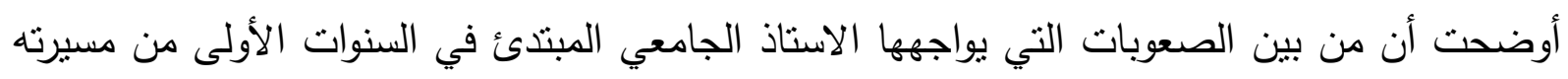

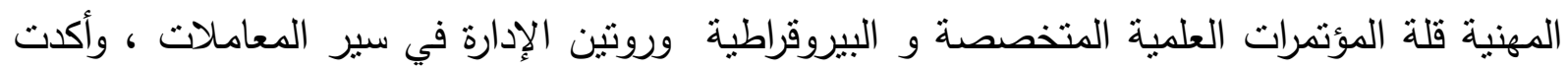
دراسة (سكر،2013) على أهمية التقييم المستمر والمتابعة الدائمة لأداء وسلوك أعضاء هيثة فيئة التدريس

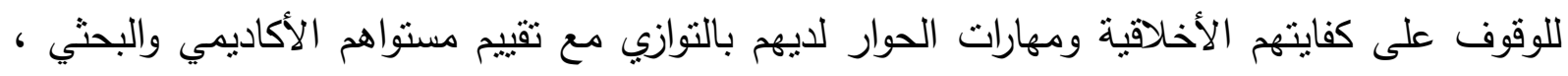

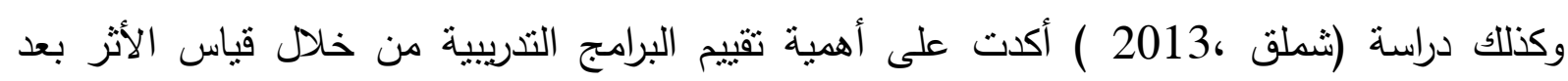

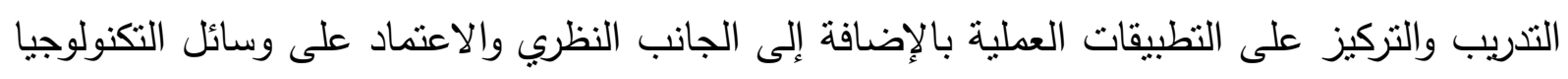

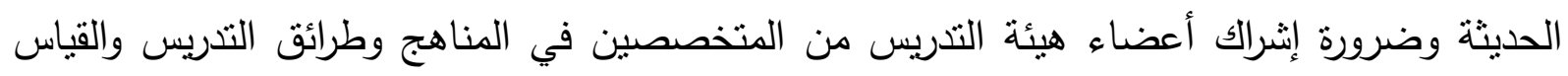

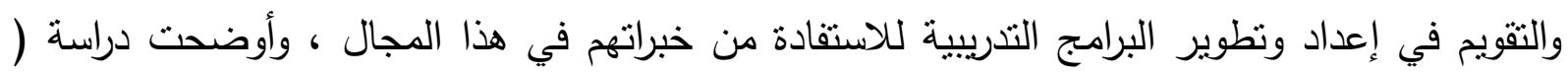

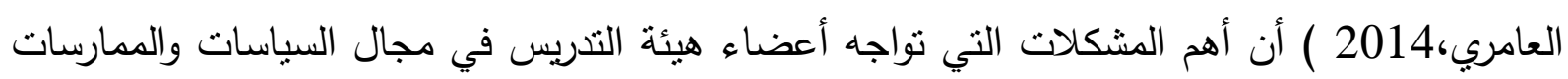

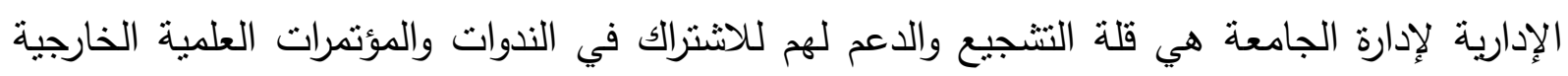
وغلبة البيروقراطية والروتين الممل على أجواء العمل الإداري وضعف الإداء عملية التدريب والتأهيل للأعضاء 
الجدد وندرة البرامج المتخصصة للنطوير المهني والتعليم المستمر التي توفرها الجامعة لأعضائها ، أما

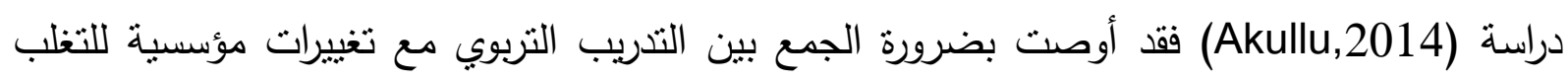

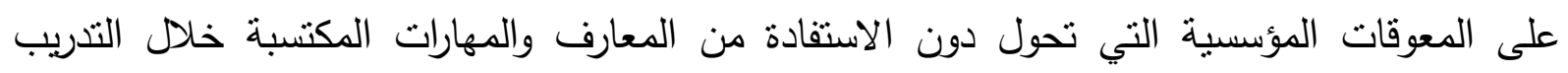
ومعالجتها بشكل متزامن ، وأنه يجب تجاوز نموذج العجز في التطوير المهني المستمر بالاعتماد على الإنى

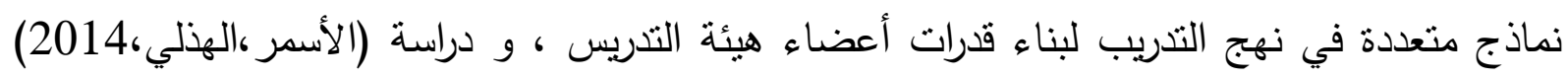

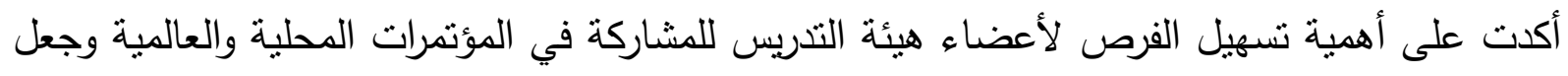
ذللك شرطاً من شروط الترقية مما يساهم في رفع مستوى نموهم المهني ، وكنلك دراسة (داوود ،

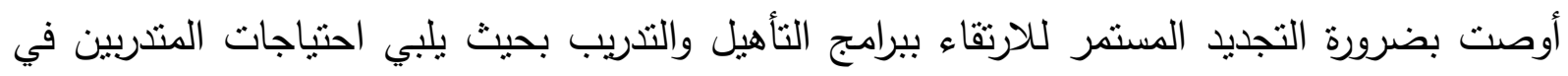

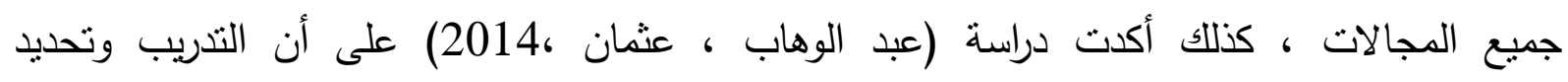

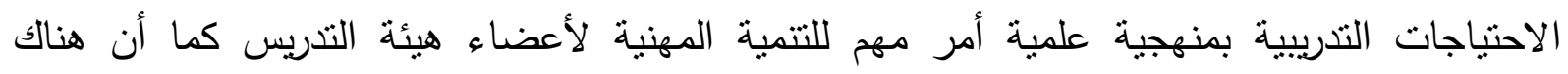

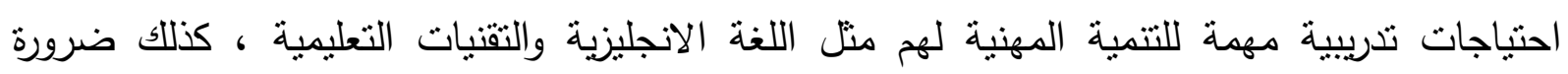

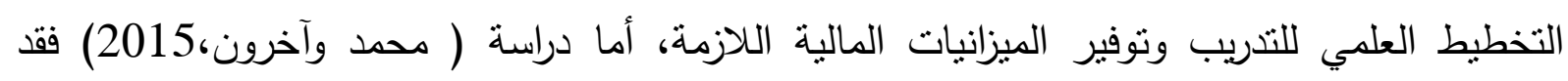

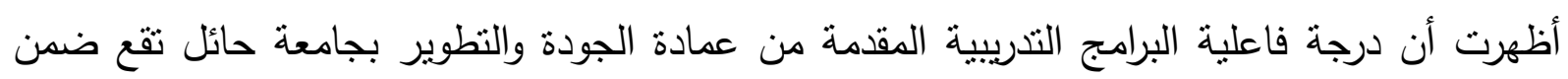

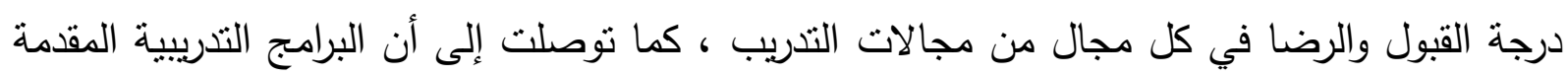

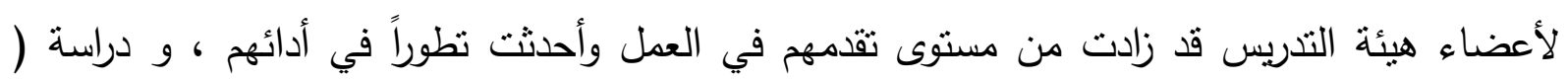

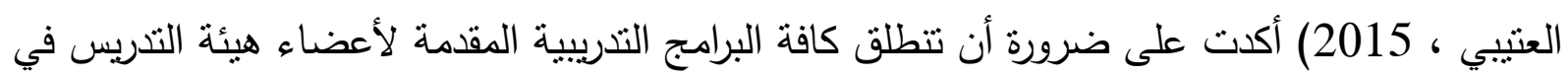

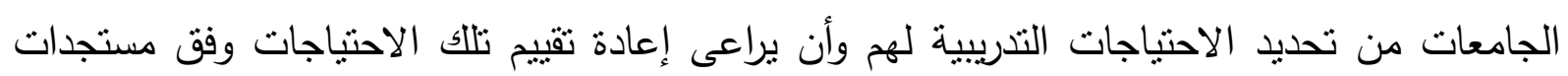

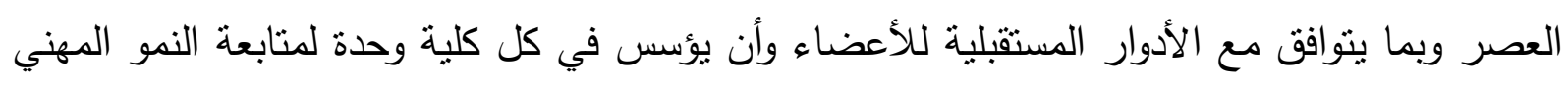

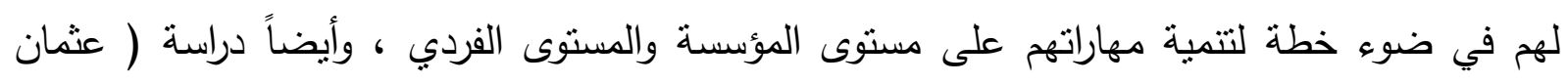

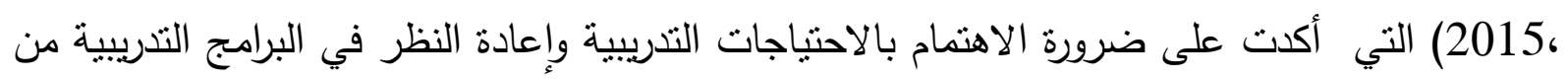

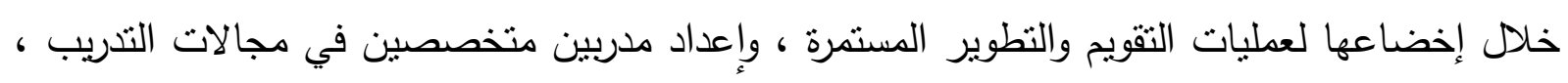
وإعطاء الوقت الكافي لمدة الدورات التدريبية بما يتتاسب مع كل معيار من معايير الاحتياجات التنريبية

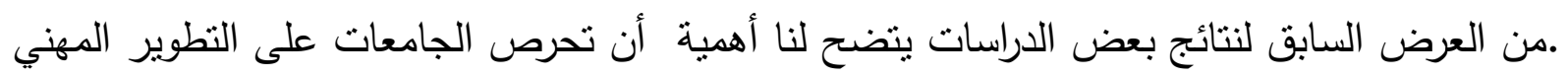

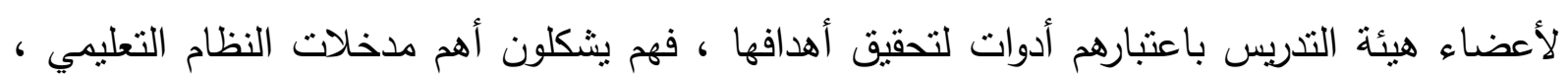

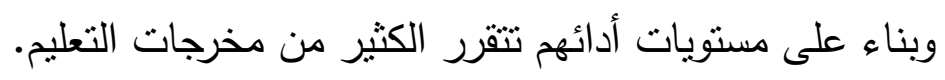

كما يتضح لنا أهمية تحديد الاحتياج التدريبي لعضو هيئة التدريس وعلاقته بكفاءة الععل ، حيث لا بد

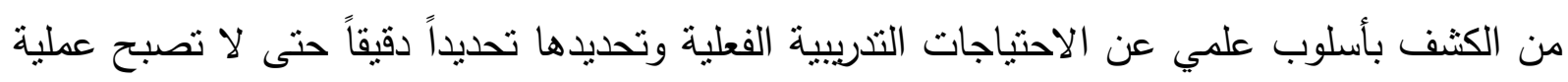

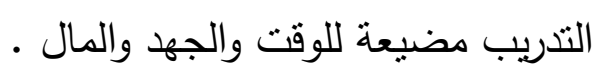


ومن ثم يمكن تحديد مشكلة الدراسة في التساؤل التالي :

( ما مدى فاعلية البرامج التدريبية في تلبية احتباجات أعضاء هيئة التدريس في جامعة الأميرة نورة بنت

عبد الرحمن )

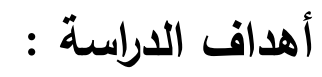

- - الهدف الرئيسي الأول : التعرف على مدى فاعلية البرامج التدريبية في تلبية احتياجات أعضاء

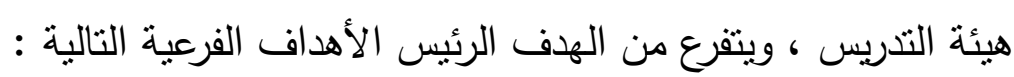

1 - التعرف على قدرة البرامج التدريبية على تلبية احتياجات أعضاء هيئة التدريس.

ץ- التعرف على الإجراءات والأساليب المتبعة في تحديد الاحتباجات التنربيية r- التعرف على المعوقات التي تحد من فاعلية البرامج التدربيية.

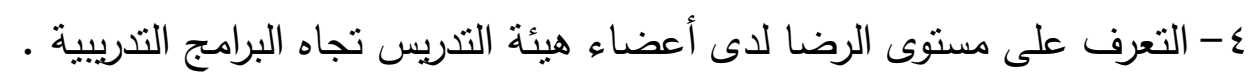

- الهدف الرئيسي الثاني : التوصل إلى مقترحات لزيادة فاعلية البرامج التدريبية لأعضاء هيئة التدربس.

\section{تساؤلات الاراسة :}

- التساؤل الرئيسي الأول : ما مدى فاعلية البرامج التدريبية في تلبية احتباجات أعضاء هيئة

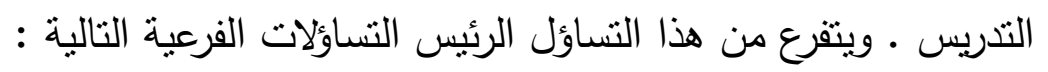

1- ما مدى قدرة البرامج التدريبية على تلبية احتياجات أعضاء هيئة التدريس.

r- ما الإجراءات والأساليب المنبعة في تحديد الاحتياجات التدريبية

ب- ما المعوقات التي تحد من فاعلية البرامج التدريبية.

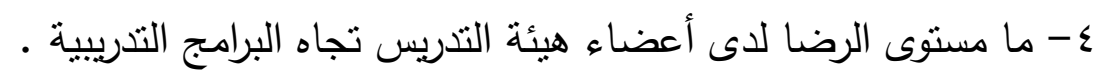

- - التساؤل الرئيسي الثناني : ما المقترحات لزيادة فاعلية البرامج التدريبية لأعضاء هيئة التدريس.

\section{المفاهيم المستخدمة في الدراسة : \\ - الاحتياجات التدريبية :}

هي حجم الفجوة مابين الأداء الفعلي من قبل الفرد ( من حيث النوع والكم )

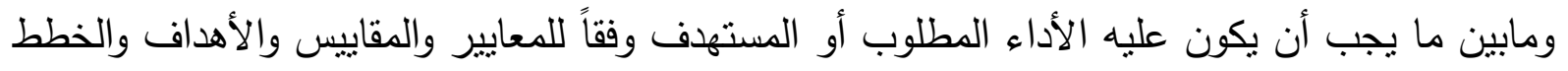

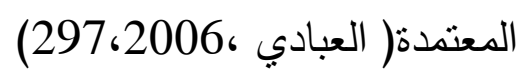


ويقصد بها تحديد السلوك أو الأداء الذي نسعى إلى تغييره أو تطويره حتى

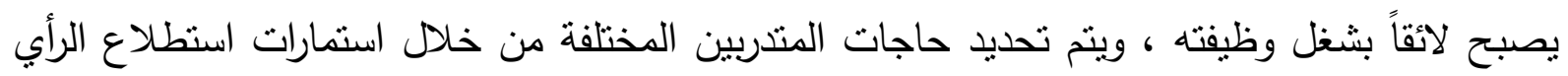
والاستبانات والمقابلات التي تحصل من فترة إلى أخرى للتعرف إلى الواقع التعليمي ( خليل ،2013) -الفاعلية :

عرفها معجم مصطلحات العلوم الاجتماعية بأنها : الظاهرة التي لها القدرة على إنتاج أثز

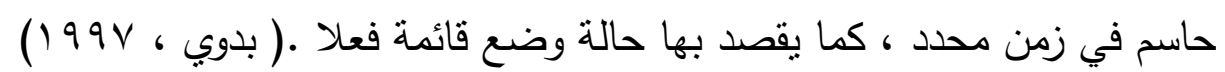
Catherine ( الفاعلية بأنها القدرة على تحقيق النتيجة المقصودة

(,Angus, 2005,555

وتعرف أيضا بأنها الدرجة التي بمقتضاها ينت إنجاز الأهداف(John,Phyllis,2000,3)

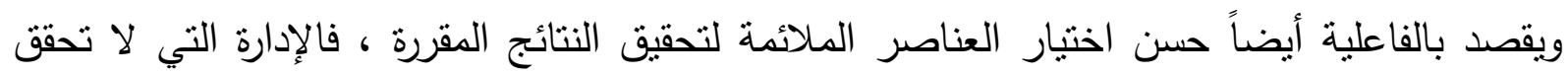

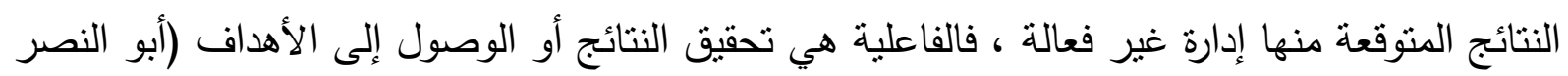
(209، 2004، ويقصد بالفاعلية في هذه الدراسة : قدرة البرامج التدريبية على تحقيق الأهداف وفق معايير محددة لتلبية

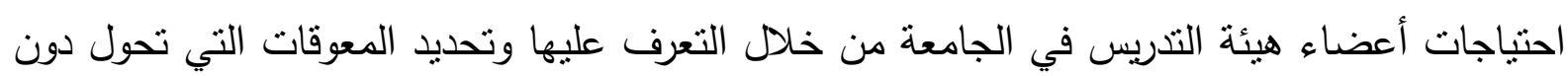

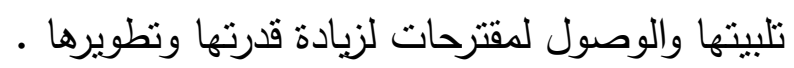
- عضو هيئة التدريس :

كل من يقوم بندريس مقررات على مستوى الجامعة ويشغل وظيفة أستاذ ،

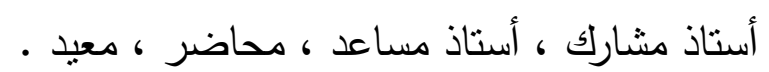

الاطار النظري للاراسة :

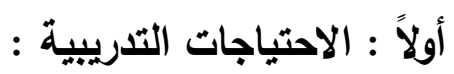

الاحتياجات التدريبية هي مجموعة التغيرات والتطورات المطلوب إحداثها بصورة إيجابية في معارف ومهارات وسلوكيات العاملين سواء للتغلب على نقاط الضعف أو المشاكل التي تحول دون تحقيق النتائج المرجوة أو لرفع وتحسين معدلات الأداء أو لإعداد العاملين لمقابلة التغير والتطور في محيط أعمالهم

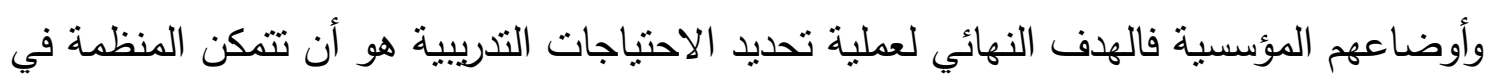
النهاية من الإجابة على الأسئلة الآتية (من هم الأثخاص المطلوب تدريبهر ؟ وعلى ماذا سيتدربون ؟ وما نوع ومجال و مستوى التدريب المطلوب لهم ؟ ومتى يتم تدريب هؤلاء ؟ (الكفافي ، 2007 ، 169) وينظر للاحتياجات التدريبية على أنها : 
- معلومات واتجاهات ومهارات وقدرات فنية أو سلوكية براد تتميتها أو تعديلها أو تغييرها. - - تمثل نواحي ضعف أو نقص جوانب فنية أو إنسانية ، حالية أو محتملة في قدرات العاملين أو معلوماتهم أو اتجاهاتهم أو مشكلات محددة يراد حلها .

- عملية مستمرة غير منتهية نتيجة للتغيرات التتظيمية أو التكنولوجية أو الانسانية. - توفر مايمكن تسميته باستمرارية النضج والثقويم الذاتي ، فتحديد الاحتياجات التدريبية يسمح بالمراجعة المستمرة للواقع ودوره في الوصول إلى وضع أفضل. - - أنها بوجه عام أهداف للتنريب تسعى المنظمة إلى تحقيقها ، فالتدريب لا يكون إلا إذا كانت هناك

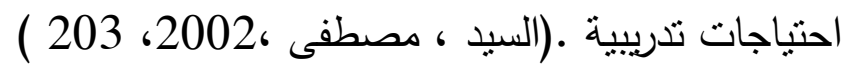
وتعتبر مرحلة تحديد الاحتياجات التدريبية الركيزة الأساسية التي تقوم عليها إستراتيجية أي مؤسسة لتنريب مواردها البشرية ، وهي تتميز بكونها متجددة ومستمرة وحالية ومستقبلية.

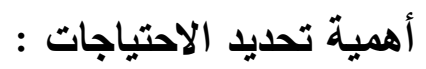
1- نساعد على التخطيط للبرامج التدريبية . r- تساعد على توفير الوقت للمنشأة.

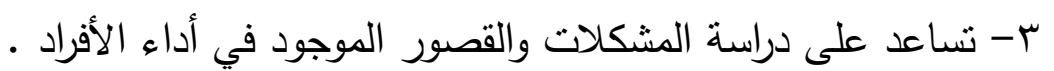
ع - تعمل على فحص الفجوة بين أهداف المنشأة والوضع القائم .

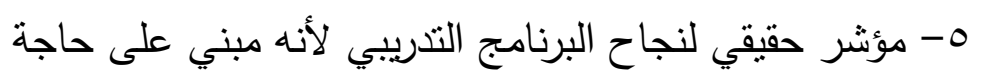

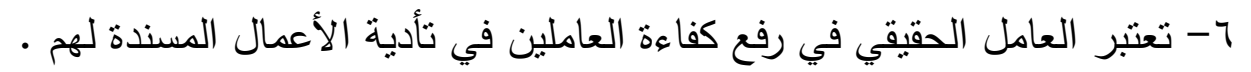

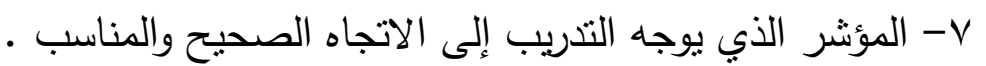

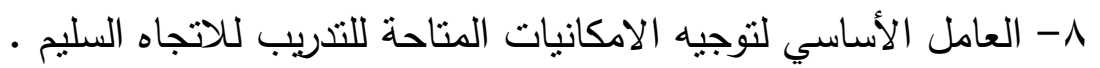

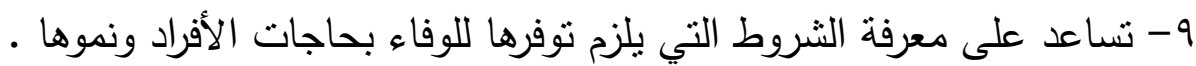

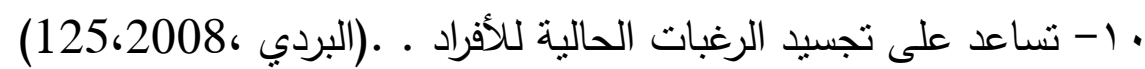

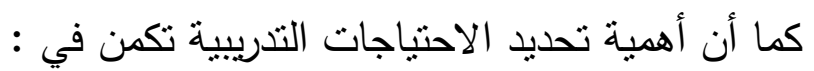

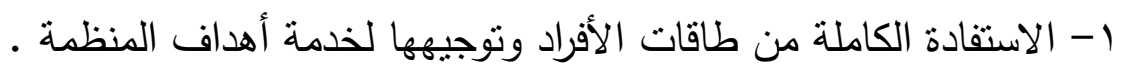
r- رغبة المنظمة في التطور ورفع معيار الجودة لديها ومواكبة النطور العالمي . r- توجيه المصروفات من قبل المنظمة التوجيه السليم الذي يضمن نوعية المردود .

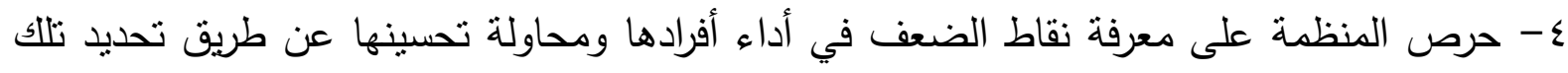

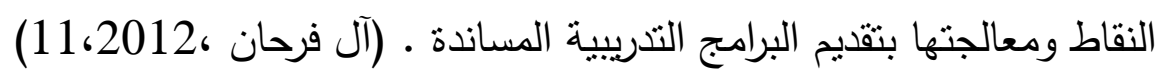




\section{تصنيف الاحتياجات التدريبية:}

إن تحديد الاحتياجات التدريبية يصنف إلى ثلاث مجموعات مرتبة هرمياً:

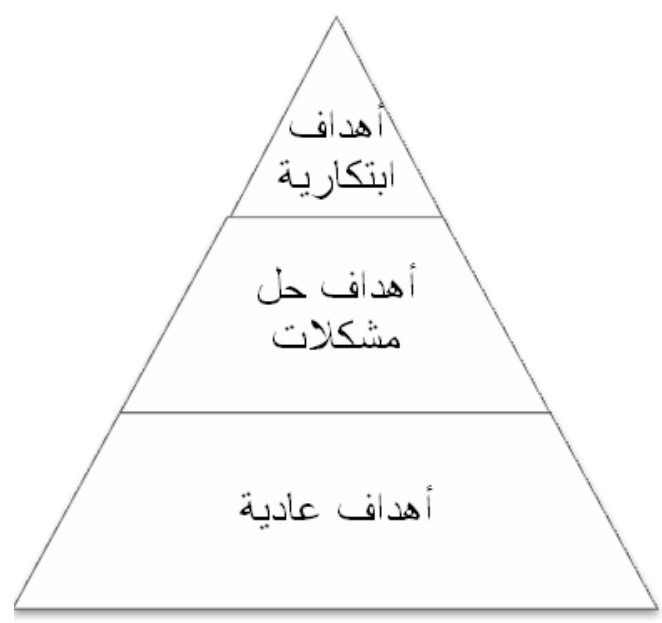

1- الأهداف العادية : وهي أهداف تساعد التنظيم في الاستمرار بمعدلات الكفاءة المعتادة وتدعم القدرات والمهارات للحفاظ على بقائها. ץ- الأهداف لحل المشكلات : للكثف عن مشكلات محددة تعاني منها المنظمة وتحليلها ودراسة أسبابها و دوافعها لتوفير الظروف المناسبة للتغلب عليها. r- الأهداف الابتكارية أو الابداعية : وتعتبر من أعلى المهام وتهدف إلى تحقيق أهداف غير عادية ومبتكرة ترفع مستوى الأداء نحو آفاق لم يسبق التوصل إليها وتحقق تميزاً واضحاً وتخلخل التوازن وتكسر التر الجمود والروتين وتتطلع إلى مواقف خارقة للعادة و تحدث خلخلة في المألوف (الطعاني ،2006، 166)

\section{مصادر التعرف على الاحتياجات التدريبية} لمعرفة الاحتياجات التدريبية مصادر كثيرة من أهمها: 1. بـ مهام الوظيفة وواجباتها ومسؤولياتها والمنطلبات الأساسية لشغلها. r. معدلات الأداء المطلوبة للوظائف وبمقارنتها بأداء العاملين الذين يشغلونها تعتبر مصدر مهم من مصادر التعرف على الاحتياجات التدريبية. r. تقارير الأداء الوظيفي التي تحرر من قبل المدير المباشر أو المشرف المسئول. ع. المستجدات والتطورات التي طرأت على الوظيفة تعد مؤشراً للاحتباجات التدريبية لمواكبة هذا التطور . 
ه. العاملون في الحقل نفسه هم أنفسهم أقدر الناس على تحديد احتباجاتهم التدريبية ا. اهداف المؤسسة تعطينا مؤشراً عاماً على الاحتياجات التدريبية اللازمة للعاملين لتحقيق هذه الأهداف.

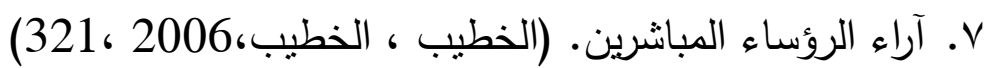

\section{معوقات تحديد الاحتياجات التدريبية :}

تواجه عملية تحديد الاحتياجات التدرييية العديد من المعوقات التي لابد من وضع الحلول المناسبة لها لكي تصل المنظمة إلى تحديد احتباجاتها بشكل سليم وبالتالي الوصول إلى أهداف ندريبية فعالة ومحددة ، وأهمها: 1- عدم تحديد الاحتياجات التدريبية بالثكل العلمي •

r- عدم وعي إدارات المنظمات بأهمية تحديد الاحتياجات التدريبية . r- السرعة في تتفيذ البرامج التدريبية وبالتالي عدم إعطاء الوقت الكافي لتحديد الاحتياجات. ع - إسناد عملية تحديد الاحتياجات التنريبية لغير المتخصصين أو عديمي الخبرة . 0- عدم دعم إدارة المنظمة لعملية تحديد الاحتباجات التدريبية مادياً.

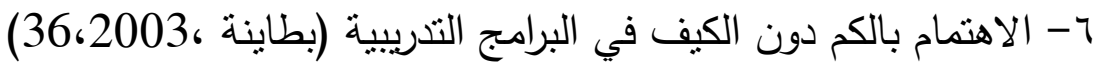
كما أن هناك عدد آخر من المعوقات منها :

-عدم النظر إلى عملية تحديد الاحتياجات التدريبية على أنها نشاط تعاوني ، بمعنى أنه لكي تتجح عملية تحديد الاحتياجات التدريبية ينبغي تعاون كل من الإدارة والجهة التي تقوم بتحديد الاحتياجات التدريبية والعاملين . -النظر للاحتياجات التدريبية بأنها واحدة متكررة بنفس النمط في حين أنها دائمة التتوع والتغير بسبب تغير الظروف وطرق العمل وبالتالي فإن عملية تحديد الاحتباجات مستمرة ومنتوعة. -عدم تعاون العامل الذي يؤدي العمل ، حيث يعتبر العامل مصدراً أساسياً في الحصول على المعلومات اللازمة لتحديد الاحتياج الندريبي • -القصور في البيانات التي تستتد إليها عملية تحديد الاحتياجات التدريبية في الكثير من المنظمات وذللك يعود

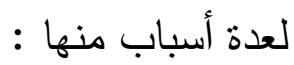
- عدم استخدام الأساليب الحديثة في جمع البيانات ومعالجتها ـ مدهاب - نقص وعي الددير أو مسئول التدريب بأهمية البيانات لنجاح عملية تحديد الاحتباجات . -كثرة وتتوع البيانات المطلوبة بحيث لا يسهل لمسئول التنريب جمعها . -قصور في نظم المعلومات .(الصيرفي ، (196،2009 
ثانياً :أعضاء هيئة التدريس في الجامعات : تواجه الجامعات العربية والسعودية على وجه الخصوص عدة تحديات بالغة الخطورة نشأت عن

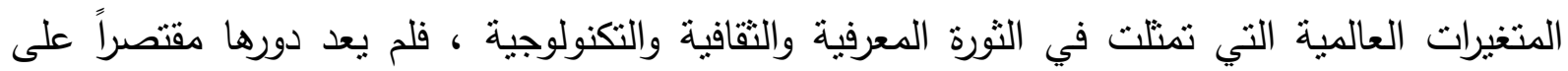
تحقيق الأهداف التقليدية والمتمثلة في التنريس والبحث عن المعرفة وتأصيلها ونشرها،بل أصبحت مسئولة أيضاً عن تحقيق التتمية السياسية والاقتصادية والاجتماعية للمتمع من خلال البحت البحث في مشكلاته

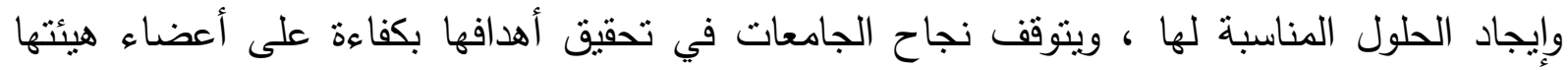

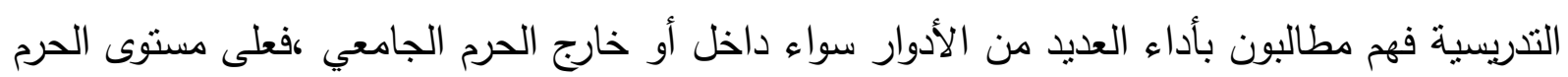

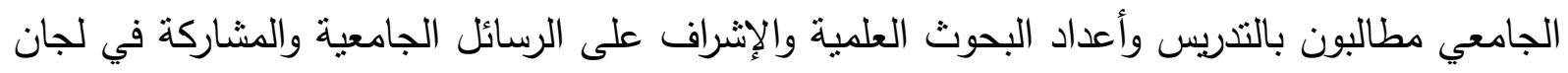

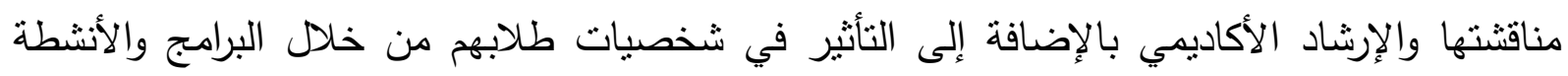

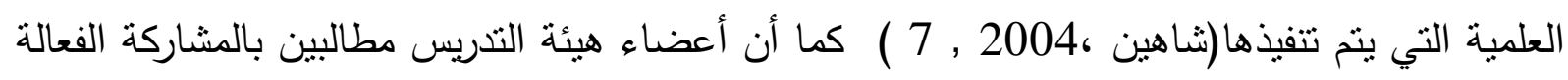

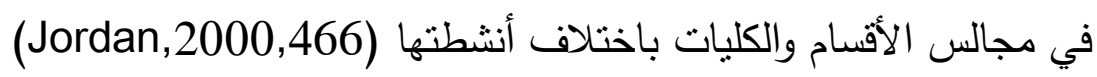
أما على مسنتى المجتمع فهر مطالبون بإجراء البحوث التطبيقية وتقديم الاسنتارات والمساهمة في التدريب والتعليم المستمر في أعمال ومؤسسات ولجان تخدم المجتمع المدني باختلاف أنشطتها ومجالاتها (الأسمر ، الهذلي ، (314، 2014). أدوار عضو هيئة التدريس الجامعي : 1- أدواره تجاه الطلاب : وتتشمل التدريس والتقويم والإرشاد والتوجيه الإشراف على بحوث الطلبة

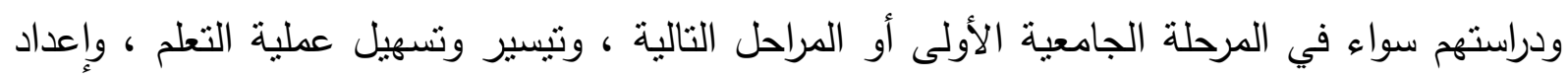

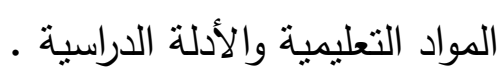
r- أدواره تجاه المؤسسة التي يعمل بها : وتتمل العمليات الإدارية بما فيها المشاركة في اتخاذ القرارات

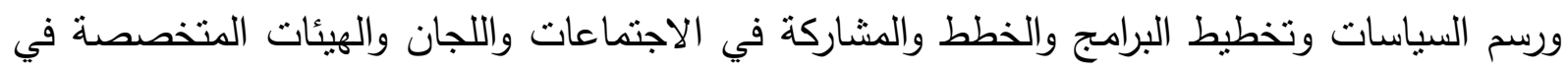
الجامعة وتمثنل الجامعة وكلياتها في المحافل الرسمية أو الثعبية.

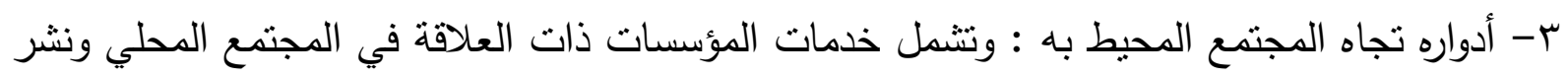

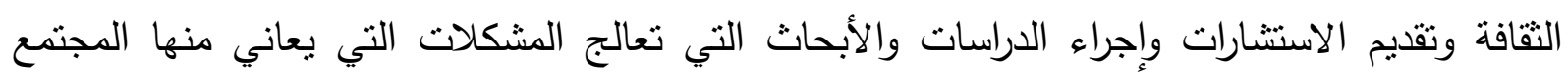

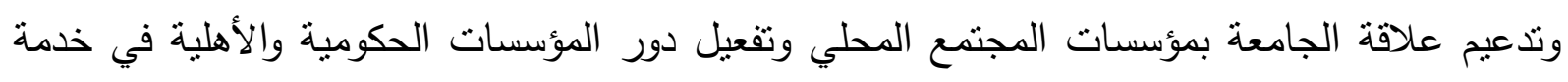

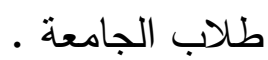
ع- أدواره تجاه نفسه : وتتمل سعيه نحو رفع مستوى تأهيله وتطوير ذاته مهنياً من خلا الاطلاع والبحث والمشاركة في المؤتمرات والندوات وحضور حلقات النقاش واللقاءات العلمية والدورات التدريبية

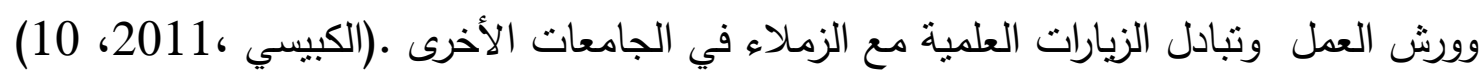

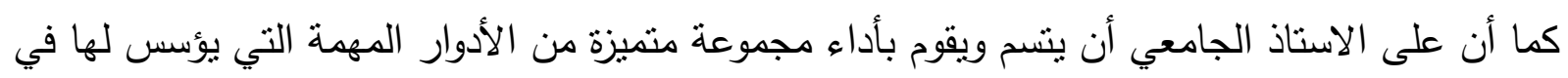

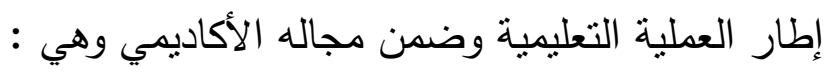


- - دوره كمخط ومنظم للوقت وذلك عبر إعطاء المحاضرات والإثراف على الطلبة وإنجاز بحوثهم والمشاركة في الأنشطة التي يقوم بها القسم أو الكلية .

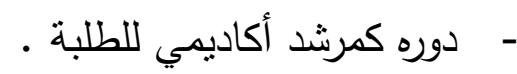

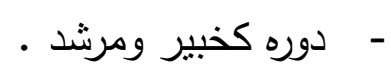

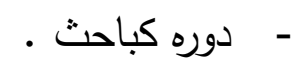

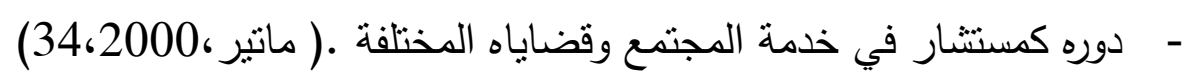

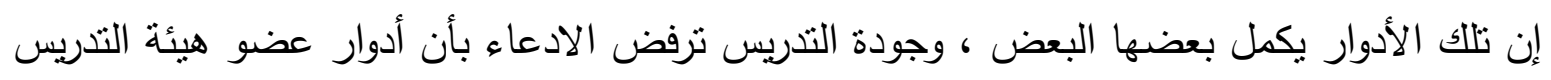

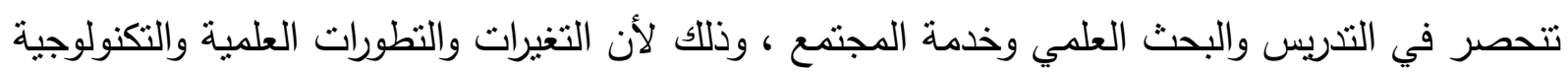

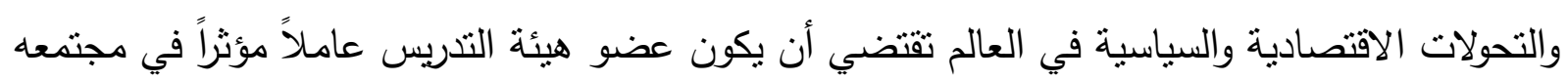

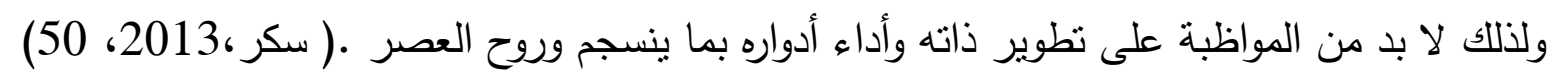

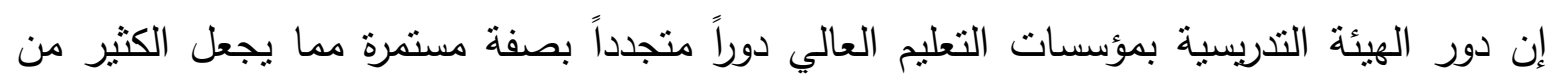

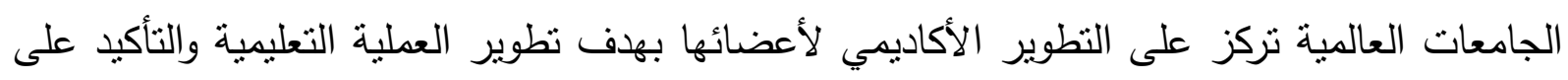

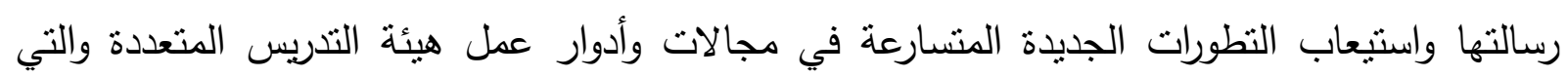

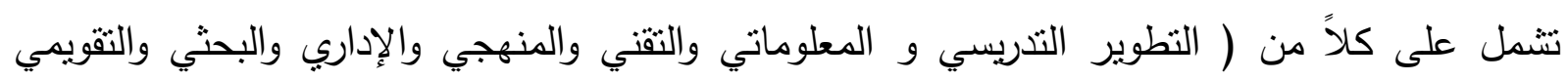

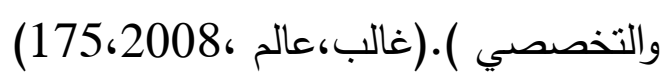
ويعد عضو هيئة التدريس المحور الأساسي في تحقيق جودة العطلية التعليمية ، وهو الحلقة الأساسية

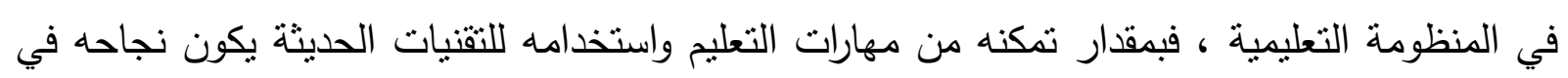

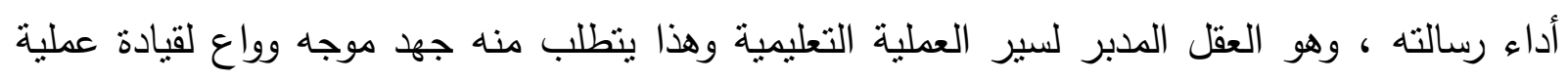

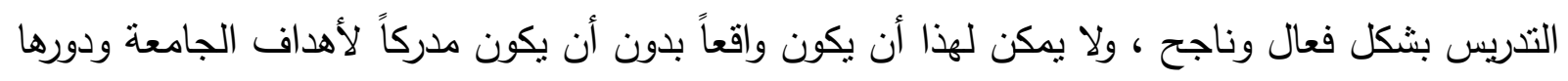

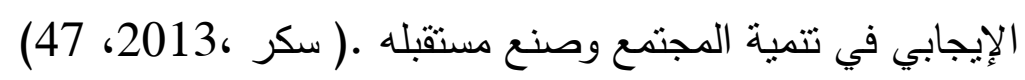

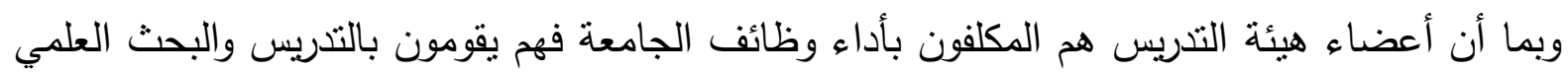

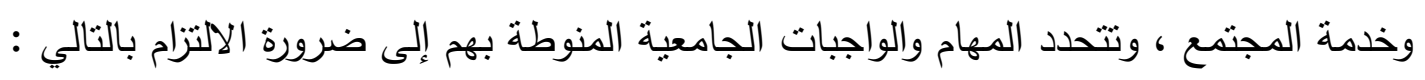

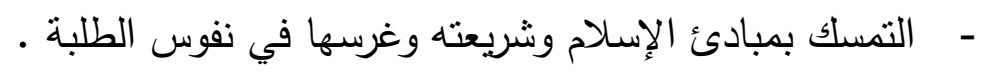
- - تجسيد القدوة الحسنة ومراعاة قيم المجتمع الحميدة . - م المحافظة على النقاليد والقيم الجامعية الأصيلة . - - توثيق الصلة مع الطلبة ورعاية شؤونهم الاجتماعية والثقافية والرياضية . -

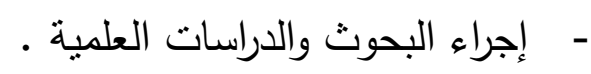

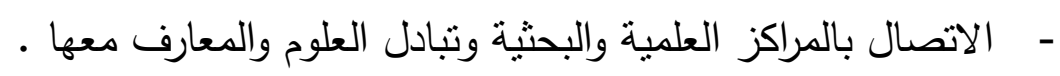

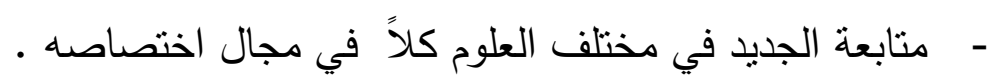


- الإثراف على بحوث الطلاب وتوجيهها بما ينمي المقدرة البحثية الإبداعية لهم .

- - إجراء الامتحانات والعمل على نطوير نظم التقويم لأداء الطلاب .

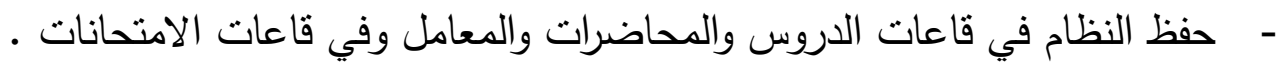

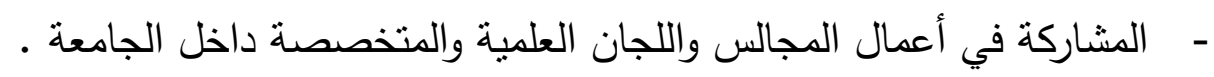

- - إتقان العمل عند أداء الواجبات والعمل على تحقيق المستوى الذي يجعل الجامعة هتميزة في

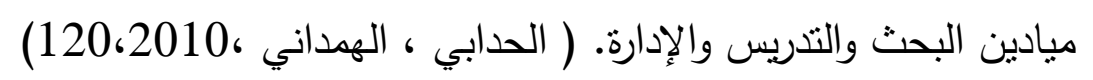

الإجراءات المنهجية للاراسة: الئة

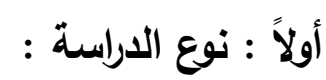

تتنمي هذه الدراسة إلى الدراسات الوصفية التي توفر المعلومات وتقوم على وصف وتقسير العلاقات بين

الظواهر (Barbara,2001,131)

و تهدف هذه الدراسة إلى التعرف على مدى فاعلية البرامج التدريبية في تلبية احتياجات أعضاء هيئة

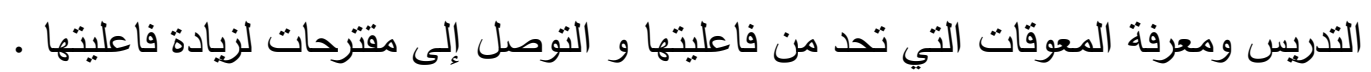

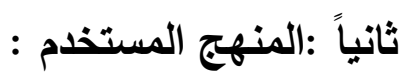

منهج المسح الاجتماعي الثنامل لأعضاء هيئة التدريس في كلية الخدمة الاجتماعية في جامعة الأميرة

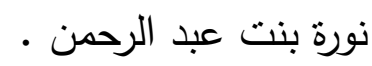

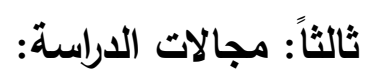

\section{المجال البشري: ( مجتمع الاراسة - عينة الدراسة )}

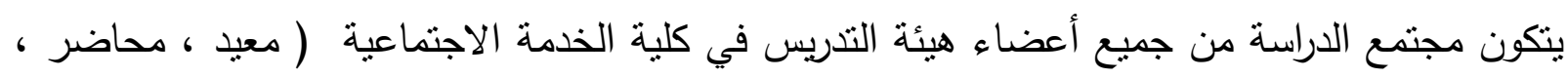

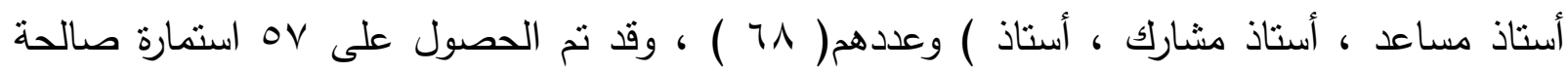

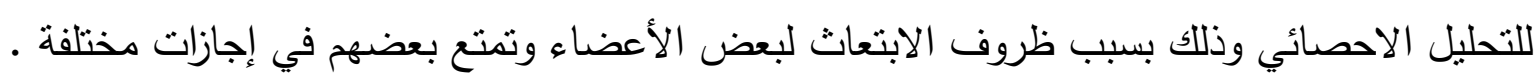
المجال المكاني: - الماني

كلية الخدمة الاجتماعية ، جامعة الأميرة نورة بنت عبدالرحمن

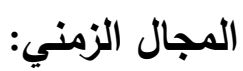
تم جمع البيانات خلال شهرين من 10 - 0 - البرات رابعاً: أداة الدراسة: البانة

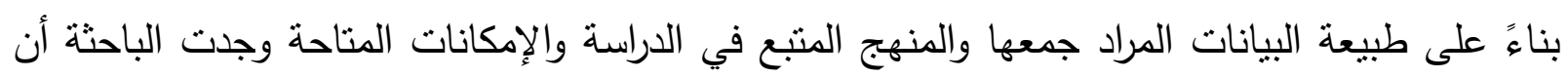
الأداة الأكثر ملائمة لتحقيق أهداف الدراسة هي ( الاستبانة ) وقد نم تصميمها بالاستفادة من الإطار

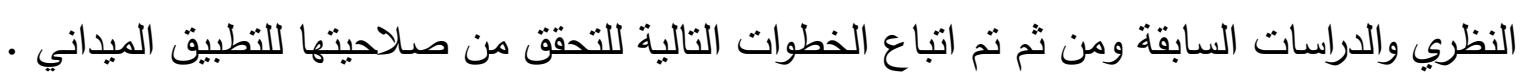


أ - الصـلق الظـاهري لـلأداة : للتعرف على مدى صدق أداة الدراسـة في قياس مـا وضعت لقياسـه تم عرضها على مجموعة من المحكمين ، وفي ضوء آرائهم نم إعداد أداة هذه الدراسة بصورتها النهائية. ب - صدق الاتساق الداخلي للأداة : تم حساب معامل الارتباط بيرسون لمعرفة الصدق الداخلي للاستبانة حيث تم حساب معامل الارتباط بين درجة كل عبارة من عبارات الاستبانة بالدرجة الكلية للمحور الذي تتنمي إليه العبارة كما توضح ذلك الجداول النالية. الجدول رقم (1) معاملات ارتباط بيرسون لعبارات المحور الأول بالارجة الكلية للمحور

\begin{tabular}{|c|c|c|c|}
\hline معامل الارتباط بالمحور & رقم العبارة & معامل الارتباط بالمحور & رقم العبارة \\
\hline **..or & 1 & $* * . . v 11$ & 1 \\
\hline$* * \cdot . \vee \wedge \wedge$ & v & $* * . . V Y \wedge$ & r \\
\hline$* * .0 \leqslant 1$ & $\wedge$ & $* * . .797$ & $r$ \\
\hline$* *$. ArT & 9 & $* * . .7 V$ & $\varepsilon$ \\
\hline$* * . . \vee \varepsilon 1$ & 1. & $* * . . \vee{ }^{\prime} \wedge$ & 。 \\
\hline
\end{tabular}

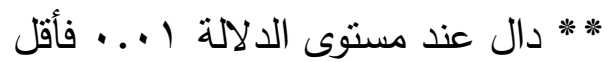

الجدول رقم (ץ) معاملات ارتباط بيرسون لعبارات المحور الثاني بالارجة الكلية للمحور

\begin{tabular}{|c|c|c|c|}
\hline معامل الارتباط بالمحود & رقم العبارة & معامل الارتباط بالمحود & رقم العبارة \\
\hline$* * . .11 \wedge$ & is & $* * .001$ & 11 \\
\hline$* * . . \mathrm{VOV}$ & 19 & $* * .071$ & ir \\
\hline$* * \cdot . \wedge \varepsilon r$ & r. & $* * . \cdot \vee \wedge$. & ir \\
\hline$* * . \wedge I V$ & $r$ & ***.. & $1 \varepsilon$ \\
\hline$* * . . V Y Y$ & rr & $* * .00 r$ & 10 \\
\hline$* * . . V Y$. & rr & $* * . . \top \Lambda \varepsilon$ & 17 \\
\hline - & - & $* * . . \vee \vee q$ & iv \\
\hline
\end{tabular}


** دال عند مستوى الدلالة ا... فأقل

الجدول رقم (ץ) معاملات ارتباط بيرسون لعبارات المحور الثالث بالارجة الكلية للمحور

\begin{tabular}{|c|c|c|c|}
\hline معامل الارتباط بالمحور & رقم العبارة & معامل الارتباط بالمحور & رقم العبارة \\
\hline **. vor & $r$. & $* * .0 Y r$ & $r \varepsilon$ \\
\hline$* * .$. ค V V & ri & $* * .07 \varepsilon$ & ro \\
\hline$* * . \wedge 1 \mathrm{~V}$ & rr & $* * . V Y I$ & rt \\
\hline$* * . .79 \leq$ & r & **..vq & rv \\
\hline **.. vo. & $r \varepsilon$ & **.. VOV & ru \\
\hline$* * \cdot . \wedge \cdot V$ & ro & $* * . . \vee 9 Y$ & rq \\
\hline
\end{tabular}

"** دال عند مستوى الدلالة ا ... فأقل

الجدول رقم (؛) معاملات ارتباط بيرسون لعبارات المحور الرابع بالارجة الكلية للمحور

\begin{tabular}{|c|c|c|c|}
\hline معامل الارتباط بالمحود & رقم العبارة & معامل الارتباط بالمحور & رقم العبارة \\
\hline$* * .17 \%$ & « & $* * . . \vee \wedge 9$ & ru \\
\hline$* * . \wedge r_{0}$ & $\varepsilon r$ & $* * * . \wedge \leq \vee$ & rV \\
\hline$* * . \wedge 9 Y$ & $\varepsilon r$ & $* * .7 .9$ & rA \\
\hline$* * \cdot . \wedge \cdot r$ & $\varepsilon \varepsilon$ & $* * \cdot . \wedge \cdot \varepsilon$ & rq \\
\hline$* * . \wedge r$. & 纟o & $* * \cdot . \wedge \cdot \wedge$ & $\varepsilon$. \\
\hline
\end{tabular}

*** دال عند مستوى الدلالة ا... فأقل

الجدول رقم (•) معاملات ارتباط بيرسون لعبارات المحور الخامس بالدرجة الكلية للمحور

\begin{tabular}{|c|c|c|c|}
\hline معامل الارتباط بالمحور & رقم العبارة & معامل الارتباط بالمحور & رقم العبارة \\
\hline$* * * .9 \cdot r$ & 01 & $* * . \vee \vee 79$ & $\leq 7$ \\
\hline$* * . V T V$ & or & $* * . . \vee \backslash V$ & $\varepsilon v$ \\
\hline$* * . . V \leq 0$ & or & $* * . . \vee \varepsilon$. & $\varepsilon \wedge$ \\
\hline
\end{tabular}




\begin{tabular}{|c|c|c|c|}
\hline$* * \cdot . \Delta r)$ & $0 \varepsilon$ & ***. .Vด & $\leqslant 9$ \\
\hline$* * .779$ & 00 & $* * . . \wedge 9$. & 0. \\
\hline
\end{tabular}

** دال عند مستوى الدلالة ا... فأقل

يتضح من الجداول (1 - 0) أن قيم معامل ارتباط كل عبارة مع محورها موجبة ودالة إحصائياً عند مستوي الدلالة (1 ... فأقل مما يدل على صدق اتساقها مع محاورها.

-

لقياس مدى ثبات أداة الدراسة تم استخدام (معادلة ألفا كرونباخ) (م) (Cronbach's Alpha) للتأكد من ثبات أداة الدراسة، والجدول رقم (T) يوضح معاملات ثبات أداة الدراسة. جدول رقم (؟) معامل ألفا كرونباخ لقياس ثبات أداة الدراسة

\begin{tabular}{|c|c|c|}
\hline ثبات المحور & عدد العبارات & محاور الاستبانة \\
\hline..$A v \cdot 1$ & 1. & مدى قررة البرامج التصريبية على تلبية احتياجات أعضاء هيئة الترريس \\
\hline $.914 \mathrm{~V}$ & $1 \mathrm{i}$ & الإجراءات والوسائل المناسبة في تحديد الاحتياجات التلريبية \\
\hline $.91 \mathrm{rr}$ & ir & المعوقات التي تحد من فاعلية البرامج التتريبية في تحقيق أهدافها \\
\hline . จง१ะ & 1. & مستوى الرضا للاى أعضاء هيئة التلريس تجاه البرامج التلريبية \\
\hline $.9 \mathrm{rvi}$ & 1. & المقترحات لزيادة فاعلية البرامج التريبيية لأعضاء هيئة الترريس \\
\hline.$\wedge \uparrow \wedge 0$ & 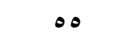 & الثبات العام \\
\hline
\end{tabular}

يتضح من الجدول رقم (؟) أن معامل الثبات العـام عال حيث بلـغ ( الاستبانة تتمتع بدرجة ثبات مرتفعة يمكن الاعتماد عليها في التطبيق الميداني.

-أساليب المعالجة الإحصائية : لتحقيق أهداف الدراسة وتحليل البيانات التي تم تجميعها، فقد تم استخدام Statistical العديد من الأساليب الإحصائية المناسبة باستخدام الحزم الإحصائية للعلوم الاجتماعية Package for Social Sciences ترميز وإدخال البيانات إلى الحاسب الآلي، ولتحديد طول خلايا المقياس الثثلاثي ( الحدود الدنيا والعليا )

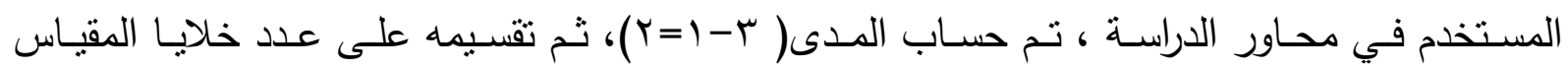




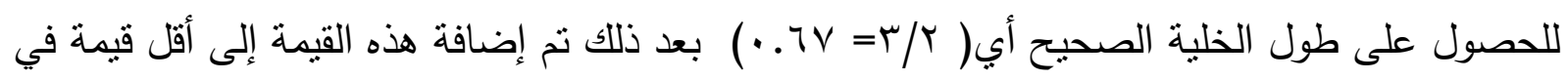
المقياس ( أو بداية المقياس وهي الواحد الصحيح) وذلك لتحديد الحد الأعلى لهذه الخلية وهكذا أصبح

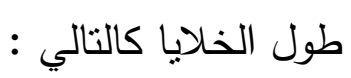

من ا إلى لآ. إيثل (لا) نحو كل عبارة باختلاف المحور المراد قياسه.

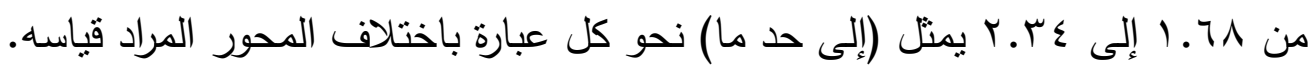

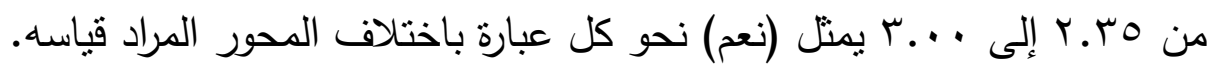
وبعد ذلك تم حساب المقاييس الإحصائية النالية :

1-التكرارات والنسب المئوية للتعرف على الخصائص الثخصية والوظيفية لمفردات عينة الدراسة وتحديد استجابات أفرادها تجاه عبارات المحاور الرئيسة التي تتضدنها الأداة .

ا ـ المتوسط الحسابي الموزون (المرجح) "Weighted Mean " وذلك لمعرفة مدى ارتفاع أو انخفاض

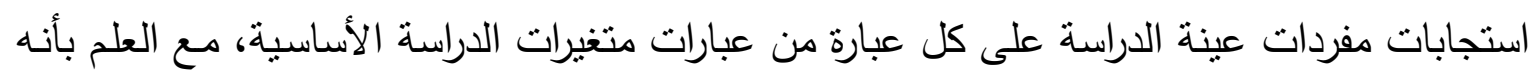
يفيد في ترتيب العبارات حسب أعلى متوسط حسابي موزون. r. المتوسط الحسابي " Mean " وذلك لمعرفة مدى ارتفاع أو انخفاض استجابات مفردات عئل عينة الدراسة

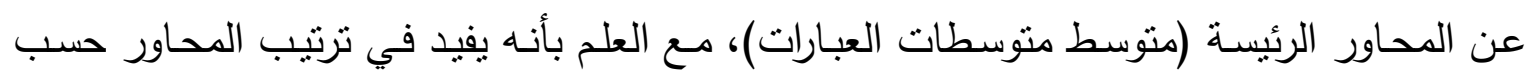
أعلى متوسط حسابي. r. تم استخدام الانحراف المعياري "Standard Deviation" للتعرف على مدى انحراف استجابات

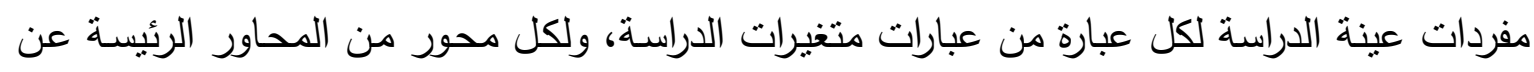

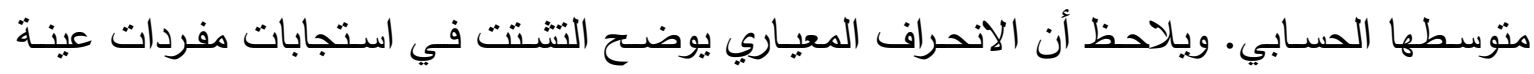

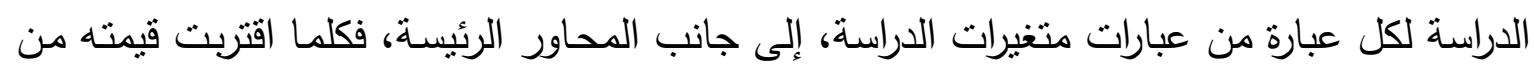
الصفر تركزت الاستجابات وانخفض تشنتها. 
- تحليل نتائج الدراسة وتفسيرها أولا : النتائج المتعلقة بوصف مفردات عينة الدراسة :-

جدول رقم (v) توزيع مفردات عينة الدراسة وفق متغير الرتبة العلمية

\begin{tabular}{|c|c|c|}
\hline النسبة & الأكرار & الرتبّة \\
\hline$v_{.}$. & $\xi$ & معيد \\
\hline $1 \leqslant$. & $\Lambda$ & محاضر \\
\hline 04.5 & YY & أستاذ مساعا \\
\hline 190 & 1 & أستاذ مشارك \\
\hline $1 \% . r$ & v & أستاذ \\
\hline$\%$ \%थ & ov & المجموع \\
\hline
\end{tabular}

يثير الجدول السابق إلى أن (rץ) من مفردات عينة الدراسة يمثلن ما نسبته ؟ .40\% رتبتهن العلمية

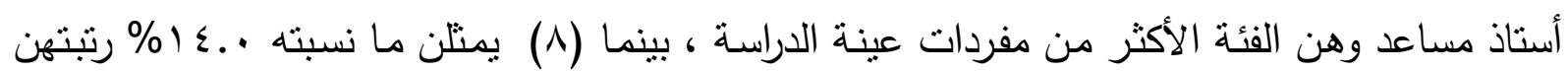

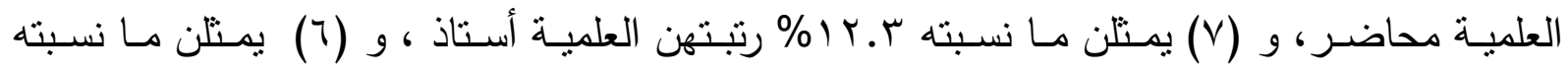

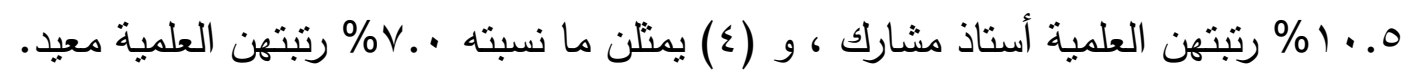

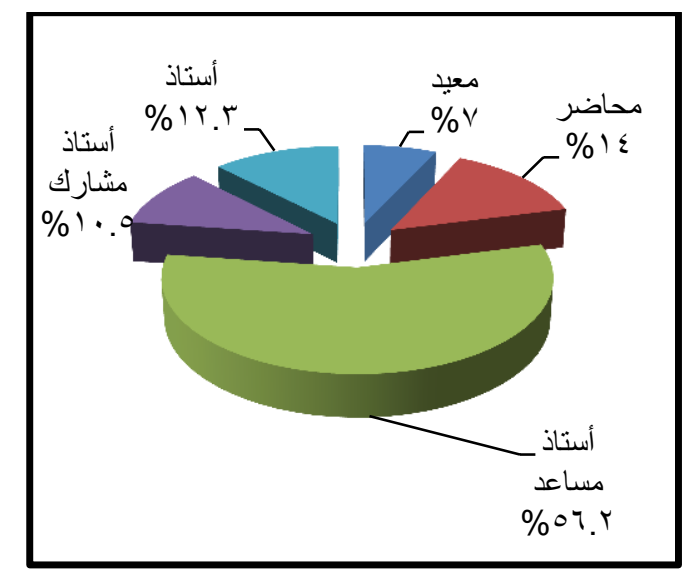


جدول رقم (^) توزيع مفردات عينة الدراسة وفق متغير عدد سنوات الخبرة

\begin{tabular}{|c|c|c|}
\hline النسبة & التكرار & سنوات الخبرة \\
\hline $1 \leqslant$. & $\Lambda$ & أقلّل من • سنوات \\
\hline Y.$\wedge$ & IV & من ·1 ـ 10 سنة \\
\hline 10.1 & 9 & من 10 - . Y سنة \\
\hline 10.1 & 9 & من ·ץ - OY سنة \\
\hline$r \leqslant .7$ & $1 \leq$ & من •r سنة فأكثر \\
\hline$\%\{\ldots$ & OV & المجموع \\
\hline
\end{tabular}

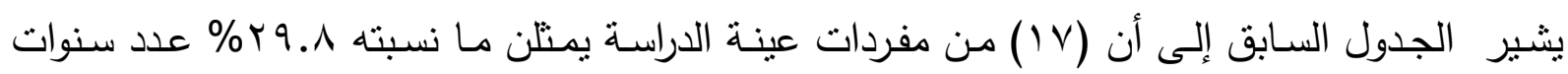
خبرتهن من • ( - 10 سنة وهن الفئة الأكثر من مفردات عينة الدراسة ، بينما (ع () يمثلن ما نسبته

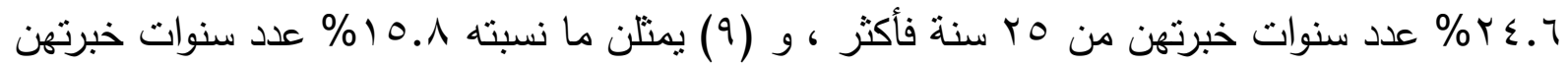

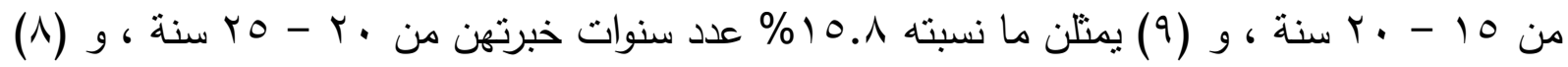
يمتلن ما نسبته .. إ \% عدد سنوات خبرتهن أقل من ه سنوات.

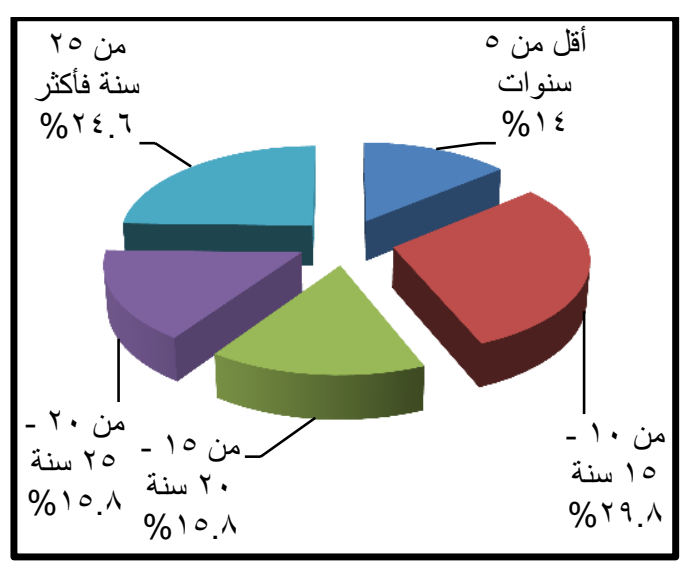

جدول رقم (9) توزيع مفردات عينة الدراسة وفق متغير عدد الدورات التدريبية

\begin{tabular}{|c|c|c|}
\hline النسبة & التكرار & عدد اللورات التكريبية \\
\hline rY.A & ir & أقل من · · دورات \\
\hline 7.4 & ro & من ·ץ - ·r دورة \\
\hline 10.1 & 9 & من · ب دورة فأكثر \\
\hline$\% \varepsilon \ldots$ & ov & المجموع \\
\hline
\end{tabular}


يشير الجدول السابق إلى أن (ro) من مفردات عينة الدراسـة يمتلن ما نسبته ع. اج\% ع عدد دوراتهن التدريبية من • r - • ب دورة وهن الفئة الأكثر من مفردات عينة الدراسة ، بينما (r ا ) يمثلن ما نسبته

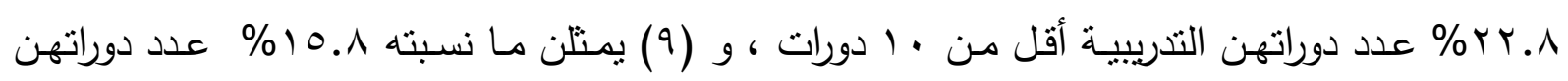
التدريبية من ·r دورة فأكثر •

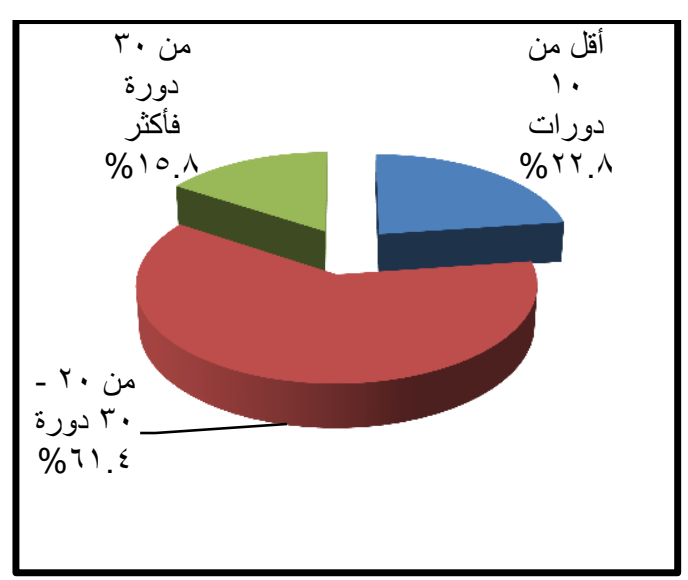

\section{ثانيا : النتائج المتعلقة بأسئلة الدراسة :--}

التساؤل الرئيسي الأول : ما مدى فاعلية البرامج التدريبية في تلبية احتياجات أعضاء هيئة التدريس . ويتفرع من هذا التساؤل الرئيس التساؤلات الفرعية التالية:

السؤال الفرعي الأول:- "ما مدى قدرة البرامج التدريبية على تلبية احتياجات أعضاء هيئة التدريس " ؟ للتعرف على مدى قدرة البرامج التريبية على تلبية احتياجات أعضاء هيئة التدريس تم حساب التكرارات والنسب المئوية والمتوسطات الحسابية والانحرافات المعياريـة والرتب لاستجابات مفردات عينـة الدراسـة على عبارات المحور وجاءت النتائج كما يوضحها الجدول التالي: 
جدول رقم (• 1) استجابات مفردات عينة الدراسة على عبارات محور مدى قررة البرامج التدريبية على تلبية احتياجات أعضاء هيئة التتريس مرتبة تنازلياً حسب متوسطات الموافقة عيدة

\begin{tabular}{|c|c|c|c|c|c|c|c|c|}
\hline \multirow[b]{2}{*}{ الرتبة } & \multirow{2}{*}{ المعياري } & \multirow{2}{*}{ الحستوسط } & \multicolumn{3}{|c|}{ درجة الموافقة } & \multirow{2}{*}{ التكرار } & \multirow[b]{2}{*}{ الفقرة } & \multirow[b]{2}{*}{ r } \\
\hline & & & موافق غير & موافق & موافق & & & \\
\hline \multirow{2}{*}{1} & \multirow[t]{2}{*}{$\because O V Y$} & \multirow[t]{2}{*}{ T.71 } & $r$ & IT & $\varepsilon r$ & ك & \multirow{2}{*}{ 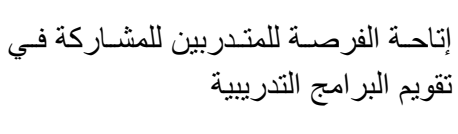 } & \multirow{2}{*}{$\varepsilon$} \\
\hline & & & $0 . r$ & Y.1. & $V T . V$ & $\%$ & & \\
\hline \multirow{2}{*}{ r } & \multirow[t]{2}{*}{$\because .09}$. & \multirow[t]{2}{*}{ T.7I } & $r$ & 17 & rᄉ & 5] & \multirow{2}{*}{ تلتــــيلية إجــر اءات الالتحـــاق بــالبر امج } & \multirow{2}{*}{$\wedge$} \\
\hline & & & $0 . r$ & Y^. $)$ & $74 . V$ & $\%$ & & \\
\hline \multirow{2}{*}{ r } & \multirow{2}{*}{.079} & \multirow[t]{2}{*}{ T.0ई } & r & TY & Tr & ك5 & \multirow{2}{*}{ توفير الحقائب التدرييية للمتدربين } & \multirow{2}{*}{7} \\
\hline & & & r.o & rᄉ. ${ }^{\prime}$ & ov. 9 & $\%$ & & \\
\hline \multirow{2}{*}{$\varepsilon$} & \multirow[t]{2}{*}{$\because .701$} & \multirow[t]{2}{*}{ r.OT } & 0 & IV & ro & 5] & \multirow{2}{*}{ بالثقنيات الحديثـة بالقاعـات التدريييـة وتجهيز هــا } & \multirow{2}{*}{ V } \\
\hline & & & $\wedge . \wedge$ & r৭.^ & $71 . \varepsilon$ & $\%$ & & \\
\hline \multirow{2}{*}{0} & \multirow[t]{2}{*}{$\cdot .7 \cdot 1$} & \multirow[t]{2}{*}{1.01} & $r$ & Tr & rT & ك & \multirow{2}{*}{ 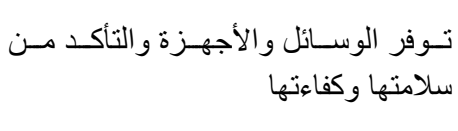 } & \multirow{2}{*}{0} \\
\hline & & & $0 . r$ & rᄉ. $\tau^{\prime}$ & 07.1 & $\%$ & & \\
\hline \multirow{2}{*}{7} & .701 & $r . \leqslant 9$ & 0 & 19 & Tr & ك & تــلليل الصــعوبات التهى قـــ تطـر أ أثثـــاء & \\
\hline & & & $\wedge . \wedge$ & מ.r & ov. 9 & $\%$ & الندريب & \\
\hline ( & $.07 \mathrm{~V}$ & T. $\leqslant \varepsilon$ & r & rA & TV & ك] & تتـــوع أســــاليب التــدريب و الأنشــــة & \\
\hline & & & r.o & $\leqslant 9.1$ & $\varepsilon \vee . \varepsilon$ & $\%$ & 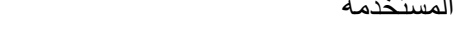 & \\
\hline & $\cdot .7 r$. & r.rq & $\varepsilon$ & TV & r7 & ك & & \\
\hline & & & $v$. & $\leqslant V \leqslant$ & $\varepsilon 0.7$ & $\%$ & & \\
\hline 9 & $\because$ OYY & t.re & 1 & re & Tr & ك] & كفــاءة المــدربين وقـدرتهم علـى إيصــال & r \\
\hline & & & 1.1 & 09.7 & rᄉ. 7 & $\%$ & المعارق والمعلومات و إكساب المهارات & \\
\hline & $\because . T V Y$ & t.r. & 7 & Tร & TV & ك & & \\
\hline & & & 1.0 & $\left.\varepsilon r_{.}\right)$ & $\Sigma V . \varepsilon$ & $\%$ & & \\
\hline & $\because \leqslant 11$ & $r . \leqslant 9$ & & & & 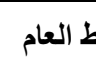 & 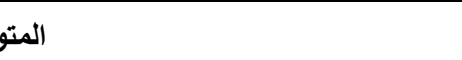 & \\
\hline
\end{tabular}


يشير الجدول السابق إلى أن قدرة البرامج التدريبية على تلبية احتياجات أعضاء هيئة التدريس تتمثل في إتاحة الفرصـة للمتدربين للمشـاركة في تقويم البرامج التدريبيـة وتسهيل إجراءات الالتحاق بها وتوفير الحقائب التدريبية وتجهيز القاعات التدريبية بالتقنيات الحديثة وتوفر الوسائل والأجهزة والتأكد من كفاءتها ، وغيرها من العوامل التي إذا تحققت ساعدت على زيادة قدرة تللك البرامج على تحقيق الأهداف المرجوة منها ، وتتفق هذه النتائج مع نتيجة دراسة (شملق ،2013 ) أكدت على أهية تقييم البرامج التدريبية من خلال قياس الأثر بعد التدريب والتركيز على التطبيقات العملية بالإضافة إلى الجانب النظري والاعتماد على وسائل التكنولوجيا الحديثة وضرورة إثنراك أعضاء هيئة التدريس من المتخصصين في المناهج وطرائق التنريس والقياس والتقويم في إعداد وتطوير البرامج التنريبية للاستفادة من خبراتهم في هذا المجال ، ودراسـة (الجبوري ،2005 ) والتي بينت أهمية التدريب للأستاذ الجامعي بهدف تمكينه من مواجهة التحديات الاستراتيجية في نظم التعليم وأهمية إيجاد صيخ جديدة لتحفيز عضو هيئة التدريس على تحسين أدائه مـع توفير التدريب المناسب على استخدام الحاسب الآلي ووسائل الاتصـال والبرمجيات لمواجهة التقدم السريع بالمهارات والمؤهلات ،و دراسـة (التركي ، 2009 )التي أوصت بضـرورة تصميم برامج تدريبية لأعضاء هيئة التدريس في مجال نوظيف مستحدثات تكنولوجيا التعليم والمعلومات ، وتدريبهم على مهارات تصميم المقرات الإلكترونية ، و نظم إدارة التعلم الإلكتروني ، كذلك دراسة (عبد الوهاب ،

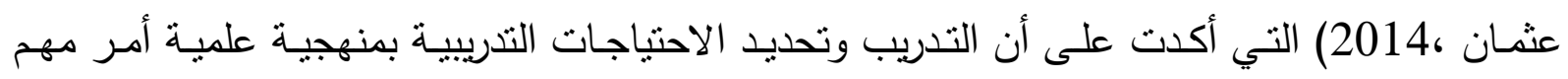
للتتمية المهنية لأعضاء هيئة التدريس كما أن هناك احتياجات تدريبية مهمة للتنمية المهنية لهم مثل اللغة الانجليزية والتقنيات التعليمية ، كذلك ضرورة التخطيط العلمي للتدريب وتوفير الميزانيات المالية اللازمة، كما تتفق مـع نتيجة دراسـة ( العتيبي ، 2015) والتي بينت ضـرورة أن تتطلق كافة البرامج التدريبية المقدمة لأعضاء هيئة التدريس في الجامعات من تحديد الاحتياجات التدريبية لهم وأن براعى إعادة تقييم تلك الاحتياجات وفق مستجدات العصر وبما ينوافق مع الأدوار المستقبلية للأعضاء وأن يؤسس في كل

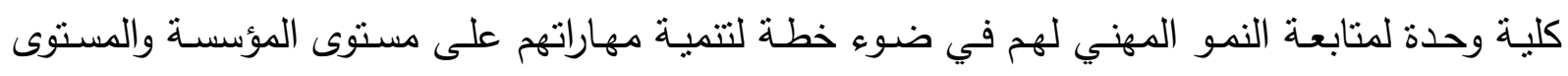
الفردي ، و دراسة (صائغ ،2005) والتي بينت أن مؤسسات التعليم العالي في الدول العربية نعاني من قصور في الاهتمام بالتمية المهنية لأعضاء هيئة التدريس ،إلى جانب نوظيف تقنية المعلومات وبناء الثبكات الالكترونية المخصصة لتطوير الأداء الوظيفي لهم. 
السؤال الفرعي الثاني: "ما الإجراءات والأساليب المتبعة في تحديد الاحتياجات التدريبية "؟ للتعرف على الإجراءات والأساليب المتبعة في تحديد الاحتياجات التدريبية تم حساب التكرارات والنسب المئوية والمتوسطات الحسابية والانحرافات المعيارية والرتب لاستجابات مفردات عينة الدراسة على عبارات المحور وجاءت النتائج كما يوضحها الجدول النالي:

جدول رقم (11) استجابات مفردات عينة الدراسة على عبارات محور الإجراءات والأساليب المتبعة في تحديد الاحتياجات التدريبية مرتبة تنازلياً حسب متوسطات الموافقة

\begin{tabular}{|c|c|c|c|c|c|c|c|c|}
\hline \multirow[b]{2}{*}{ الرتبة } & \multirow{2}{*}{ المعياري } & \multirow{2}{*}{ الحسابي } & \multicolumn{3}{|c|}{ درجة المو افقة } & \multirow{2}{*}{ النكرار } & \multirow[b]{2}{*}{ الفقرة } & \multirow[b]{2}{*}{ م } \\
\hline & & & موافق & إلى حو حـ & موافق & & & \\
\hline \multirow{2}{*}{1} & .01 & T.Yo & r & 1. & $\leqslant 0$ & ك & \multirow{2}{*}{ استقصاء الآراء (الاستطلاع) } & \multirow{2}{*}{11} \\
\hline & & & r.0 & IV.O & $\vee \wedge . q$ & $\%$ & & \\
\hline \multirow{2}{*}{ r } & $.7 \% 0$ & T.01 & $\varepsilon$ & 17 & $\overline{r V}$ & 5 & \multirow{2}{*}{ حلقات المناقشة } & \multirow{2}{*}{ iv } \\
\hline & & & $\vee$. & Y^. 1 & $7 \leqslant .9$ & $\%$ & & \\
\hline \multirow{2}{*}{ r } &. $.70 \mathrm{~V}$ & T.0 & 0 & 17 & 4 & 5 & \multirow{2}{*}{ ورش العمل } & \multirow{2}{*}{$1 \pi$} \\
\hline & & & $\Lambda . \wedge$ & rA. ${ }^{\prime}$ & $7 r .4$ & $\%$ & & \\
\hline \multirow{2}{*}{$\varepsilon$} &. .7 .9 & Y. $\leqslant 7$ & v & IV & Tr & 5 & \multirow{2}{*}{ تقويم الآداء الفعلي للمفردات } & \multirow{2}{*}{ rr } \\
\hline & & & 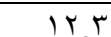 & rqA & or 9 & $\%$ & & \\
\hline \multirow{3}{*}{ 。 } &. .71. & $T . \Sigma Y$ & 7 & ri & $r$. & 5 & \multirow{3}{*}{ تحليل البيئة للمنظمة } & \multirow{3}{*}{ זr } \\
\hline & & & & & & & & \\
\hline & & & $1 \cdot .0$ & $\Gamma 7.1$ & 0.7 & $\%$ & & \\
\hline \multirow{2}{*}{7} &.$V Y T$ & r.rq & $\wedge$ & 19 & $r$. & 5 & \multirow{2}{*}{ المسوح } & \multirow{2}{*}{$1 \varepsilon$} \\
\hline & & & $1 \leqslant$. & $\pi$ & or 7 & $\%$ & & \\
\hline \multirow{2}{*}{ v } &. .17. & T.YY & 1. & 19 & TA & 5 & \multirow{2}{*}{ تحليل الآداء } & \multirow{2}{*}{ r. } \\
\hline & & & $1 \times 0$ & Tr & $\leqslant 9,1$ & $\%$ & & \\
\hline \multirow{3}{*}{$\wedge$} &.$\quad \mathrm{VAr}$ & T.RY & 11 & IV & rq & 5 & \multirow{3}{*}{ در اسة السجلات و التقارير } & \multirow{3}{*}{11} \\
\hline & & & & & & & & \\
\hline & & & 17.1 & 17.0 & $0 . .7$ & $\%$ & & \\
\hline 9 &.$V V \varepsilon$ & T.YA & 11 & 19 & TV & ك & الملاحظة & 10 \\
\hline
\end{tabular}




\begin{tabular}{|c|c|c|c|c|c|c|c|c|}
\hline \multirow{3}{*}{ الرتبة } & \multirow{3}{*}{ المعياري } & \multirow{3}{*}{ الحسابي } & \multicolumn{3}{|c|}{ درجة المو افقة } & \multirow{2}{*}{$\begin{array}{c}\text { النكرار } \\
\text { \% }\end{array}$} & \multirow{3}{*}{ الفقرة } & \multirow{3}{*}{ r } \\
\hline & & & موافير & مو ملى حد & موافق & & & \\
\hline & & & 19.4 & Tr.T & $\varepsilon Y . \varepsilon$ & $\%$ & & \\
\hline \multirow{2}{*}{1.} & $\cdot . \wedge 11$ & 5.19 & $\overline{1 \%}$ & 111 & ro & 5 & \multirow{2}{*}{ تحليل المهام } & \multirow{2}{*}{ r) } \\
\hline & & & $Y \leqslant .7$ & 4.7 & $\varepsilon r .9$ & $\%$ & & \\
\hline \multirow{2}{*}{11} &.. $\mathrm{V01}$ & 5.17 & IT & $r \varepsilon$ & r) & ك5 & \multirow{2}{*}{ تحليل الوثائق } & \multirow{2}{*}{19} \\
\hline & & & r.. 1 & $\varepsilon r .1$ & $r 4.1$ & $\%$ & & \\
\hline \multirow{2}{*}{ Ir } & $\cdot . \wedge \cdot 1$ & 1.97 & 19 & r) & IV & ك5 & \multirow{2}{*}{ المقابلات } & \multirow{2}{*}{ ir } \\
\hline & & & ז.r & r..1 & $r 9.1$ & $\%$ & & \\
\hline \multirow{2}{*}{ ir } & $\cdot . \wedge 11$ & 1.17 & $\overline{T r}$ & 19 & 10 & ك & \multirow{2}{*}{ الاختبارات } & \multirow{2}{*}{17} \\
\hline & & & $\varepsilon . \varepsilon$ & rT.r & rฯ.r & $\%$ & & \\
\hline & .010 & T.rT & \multicolumn{6}{|c|}{ المتوسط العام } \\
\hline
\end{tabular}

يشير الجدول السابق إلى أن أبرز الإجراءات والأساليب المتبعة في تحديد الاحتباجات التدريبية تتمثل في استقصاء الآراء (الاسنطلاع) وحلقات النقاش وورش العمل و تقويم الأداء الفعلي للمفردات و تحليل البيئة للمنظمة وغيرها من الوسائل والإجراءات التي تسهم في التعرف على الاتجاهات والرغبات والميول بشكل

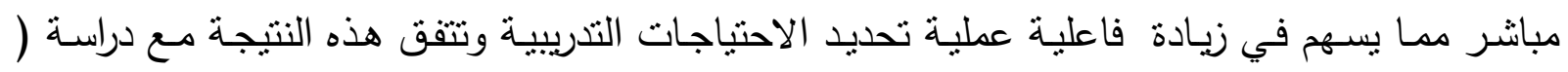

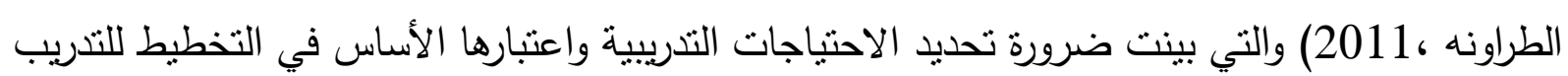

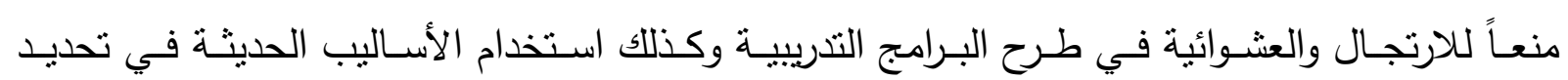
الاحتياجات مثل : تحليل بيئة المنظمة والتحديد الذاتي وتحليل الوثائق وتحليل مشاكل الجماعات وغيرها

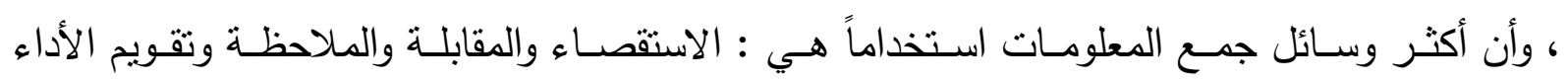
والاختبارات والحلقات النقاثية واللجان ، ودراسة ( بن موسى ،2007) التي نوصلت إلى نتائج من

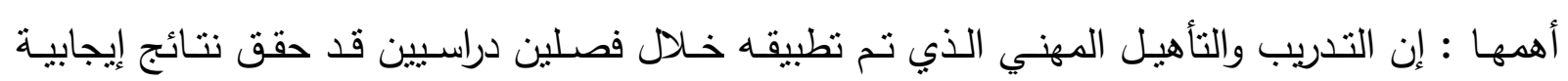
انعكست على مستوى التحصيل العام للطلاب ، وأوصت بضرورة الاستمرار في تقييم جميع عناصر

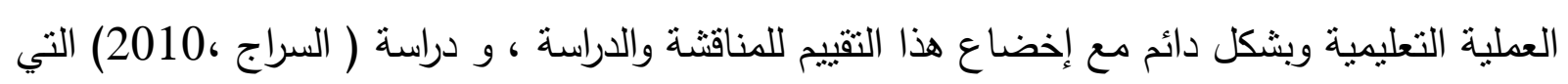
ذكرت أن هناك معوقات لعملية تحديد الاحتياجات التنريبية دنها: عدم وجود موارد مالية كافيـة تدعم 
عملية تحديد الاحتياجات التدريبية وعدم وجود خطط واضحة لتحديدها وعدم وجود نظام بشكل منتظم لتحديدها وعدم التحديد الدقيق لمعايير الأداء النموذجي للعاملين بالمنظمة وعدم توفر الوقت الكافي لدى القائمين على عمليـة تحديد الاحتياجـات بالإضـافة إلى افتقارهم للخبرة في تطبيق الأسـاليب المختلفة لتحديدها.

السؤال الفرعي الثالث :- "ما المعوقات التي تحد من فاعلية البرامج التدريبية في تحقيق أهدافها " ؟ للتعرف على المعوقات التي تحد من فاعلية البرامج التدريبية في تحقيق أهدافها تم حساب التكرارات والنسب المئويـة والمتوسطات الحسابية والانحرافات المعياريـة والرتب لاستجابات مفردات عينة الدراسـة على عبارات المحور وجاءت النتائج كما يوضحها الجدول التالي:

جدول رقم (r 1) استجابات مفردات عينة الاراسة على عبارات محور المعوقات التي تحد من فاعلية البرامج التدريبية في تحقيق أهدافها مرتبة تنازلياً حسب متوسطات الموافقة

\begin{tabular}{|c|c|c|c|c|c|c|c|c|}
\hline \multirow[b]{2}{*}{ 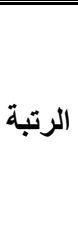 } & \multirow[b]{2}{*}{ المعياري } & \multirow[b]{2}{*}{ الحستوسي } & \multicolumn{3}{|c|}{ لدرجة الموافقة } & \multirow{2}{*}{ التكرار } & \multirow[b]{2}{*}{ 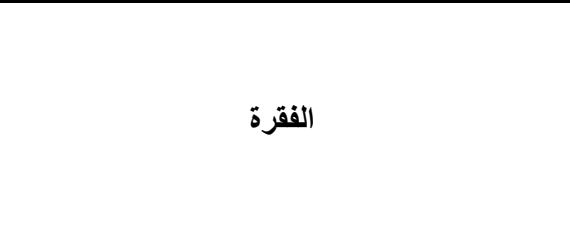 } & \multirow[b]{2}{*}{$p$} \\
\hline & & & موافق & 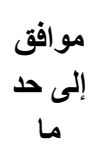 & 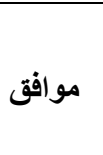 & & & \\
\hline \multirow{2}{*}{1} &. .117 & r.97 & - & r & 00 & ك & \multirow{2}{*}{ كثرة الأعباء الدكلف بها عضو هيئة التنريس } & \multirow{2}{*}{$r \varepsilon$} \\
\hline & & & - & r.o & 97.0 & $\%$ & & \\
\hline \multirow{2}{*}{ r } &. $.79 \varepsilon$ & 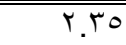 & $\bar{V}$ & $\overline{T H}$ & TV & 5 & \multirow{2}{*}{ السر عة في تتفيذ البرامج التدريبية } & \multirow{2}{*}{ זr } \\
\hline & & & IT.r & $\xi . \varepsilon$ & $\varepsilon V . \xi$ & $\%$ & & \\
\hline \multirow{2}{*}{$r$} &. .119 & T.TO & $\lambda$ & Tr & rर & ك & \multirow{2}{*}{ المستقبلية على الاحتياجـات التدرييـة الحاليـة دون } & \multirow{2}{*}{$r \varepsilon$} \\
\hline & & & $1 \leqslant$. & ז. & $\leqslant 9.1$ & $\%$ & & \\
\hline \multirow{2}{*}{$\varepsilon$} & $\cdot V \leqslant$. & $r . \mu \mu$ & 9 & $r$. & ץA & ك & \multirow{2}{*}{ 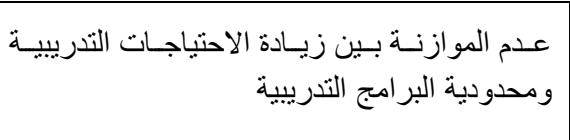 } & \multirow{2}{*}{ ro } \\
\hline & & & 10.1 & ro. 1 & $\leqslant 9.1$ & $\%$ & & \\
\hline \multirow{2}{*}{0} &. VAr & T.TY & 11 & TV & rq & ك & \multirow{2}{*}{ الاهتمام بالكم دون الكيف في البرامج النتريبية } & \multirow{2}{*}{ rr } \\
\hline & & & 19.5 & $r 9.1$ & 0.99 & $\%$ & & \\
\hline \multirow{2}{*}{1} & $\theta V T r$ & T.KT & 1. & $T \varepsilon$ & $T r$ & s & \multirow{2}{*}{ و التطبيقية موازنــة البـر امج بـين الأهــاف النظريــة } & \multirow{2}{*}{$r}$. \\
\hline & & & IV.O & $\varepsilon r_{.} 1$ & $\varepsilon \cdot . \varepsilon$ & $\%$ & & \\
\hline
\end{tabular}




\begin{tabular}{|c|c|c|c|c|c|c|c|c|}
\hline \multirow{2}{*}{ V } & $\because \vee \wedge$ & r.19 & 1. & r & YI & ك] & \multirow{2}{*}{ لموضـوم اســـتخدام الأســـاليب التدريبيــــة المناســــة } & \multirow{2}{*}{ r } \\
\hline & & & $1 V .0$ & $\leqslant 0.7$ & r..1 & $\%$ & & \\
\hline \multirow{2}{*}{$\wedge$} & $\because \vee \vee 7$ & 5.19 & Ir & rt & זr & ك & \multirow{2}{*}{ الزمنية لها الموازنـة بـين موضـوعات البر امج و المــدة } & \multirow{2}{*}{ M } \\
\hline & & & r..1 & rᄉ. 7 & $\varepsilon \cdot . \varepsilon$ & $\%$ & & \\
\hline \multirow{3}{*}{9} & $\because \vee \vee 7$ & 5.19 & Ir & rt & rT & ك5 & \multirow{3}{*}{ عدم ربط المادة العلمية بالو اقع العملي للمتدربين } & \multirow{3}{*}{ rV } \\
\hline & & & & & & & & \\
\hline & & & r.. & $r \wedge .7$ & $\varepsilon \cdot . \varepsilon$ & $\%$ & & \\
\hline \multirow{2}{*}{$1 \cdot$} & $\because \vee \wedge \uparrow$ & $r .9$ & 10 & rt & $r \cdot$ & ك & \multirow{2}{*}{ 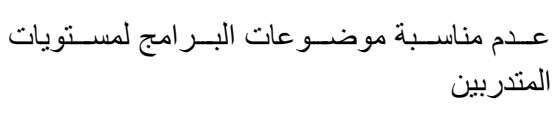 } & \multirow{2}{*}{ rq } \\
\hline & & & r.. & r^. 7 & ro.1 & $\%$ & & \\
\hline \multirow{3}{*}{11} & $\because V \wedge r$ & $1 . \wedge r$ & r & r) & $1 T$ & 5] & \multirow{3}{*}{ عدم التزام المدربين بموضو عات البرامج التدريبية } & \multirow{3}{*}{ rA } \\
\hline & & & & & & & & \\
\hline & & & $\varepsilon \cdot . \varepsilon$ & $r 7 . \wedge$ & YT.A & $\%$ & & \\
\hline \multirow{2}{*}{ ir } & $\because V \leq \cdot$ & $1.7 \mathrm{~V}$ & rᄉ & $r \cdot$ & 9 & ك & \multirow{2}{*}{ صعوبة التسجيل في البر امج التدريبية } & \multirow{2}{*}{ ro } \\
\hline & & & $\leq 9.1$ & ro.1 & 10.1 & $\%$ & & \\
\hline & $.01 \%$ & t.rt & & & & & المتوسد & \\
\hline
\end{tabular}

يشير الجدول السابق إلى أن أبرز المعوقات التي تحد من فاعلية البرامج التدريبية في تحقيق أهدافها تتمنل في كثرة الأعباء المكلف بها عضو هيئة التنريس والسرعة في تتفيذ البرامج الندريبية والتركيز على الاحتباجات الحالية دون المستقبلية وتفسر هذه النتيجة بأن كثرة الأعباء المكلف بها عضو هيئة التدريس لا يتيح له التفرغ والالتحاق بالبرامج التدريبية مما يحد من فاعلية البرامج التدريبية في تحقيق أهدافها و

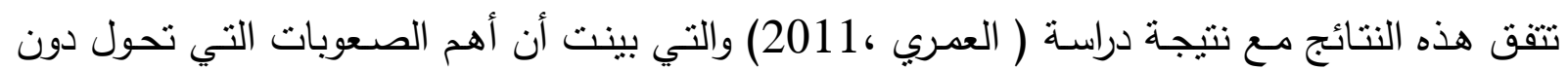
حصول أعضاء هيئة التدريس على التدريب هي كثرة الأعباء التدريسية والإدارية للعضو وتعارض أوقات تتفيذ بعض البرامج مع الجدول الدراسي وقلة الدورات في مجال التخصص الأكاديمي للعضو وانخفاض جودة بعض البرامج ،ودراسة (Kdlinski,2002) والتي بينت وجود معوقات تواجه مؤسسات التعليم عند تطبيق إدارة الجودة الثاملة ومبادئها ،كما تتفق مع نتيجة دراسة ( السراج ،2010) والتي بينت أن هناك معوقات لعمليـة تحديد الاحتياجـات التنريبيـة منهـا: عدم وجود مـوارد ماليـة كافيـة تدعم عمليـة تحديد الاحتباجات التدريبية وعدم وجود خطط واضحة لتحديدها وعدم وجود نظام بشكل منتظم لتحديدها وعدم التحديد الدقيق لمعايير الأداء النموذجي للعاملين بالمنظمة وعدم توفر الوقت الكافي لدى القائمين على عملية تحديد الاحتياجات بالإضافة إلى افتقارهم للخبرة في تطبيق الأساليب الدختلفة لتحديدها ، كما تتفق 
مع نتيجة دراسة ( العامري،2014 ) والتي بينت أن أهم المشكلات التي تواجه أعضاء هيئة التدريس في مجال السياسات والممارسات الإدارية لإدارة الجامعة هي قلة التشجيع والدعم لهم للاشتراك في الندوات والمؤتمرات العلمية الخارجية وغلبة البيروقراطية والروتين الممل على أجواء العمل الإداري وضعف عملية التدريب والتأهيل للأعضاء الجدد وندرة البرامج المتخصصة للتطوير المهني والتعليم المستمر التي توفرها

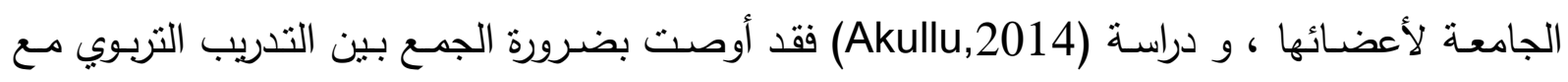
تغييرات مؤسسية للتغلب على المعوقات المؤسسية التي تحول دون الاستفادة من المعارف والمهارات المكتسبة خلال التدريب ومعالجتها بشكل متزامن ، وأنه يجب تجاوز نموذج العجز في التطوير المهني المستمر بالاعتماد على نماذج متعددة في نهج التنريب لبناء قدرات أعضاء هيئة التدريس،وما أكدت عليه دراسة ( العتيبي ، 2015) من ضرورة أن تتطلق كافة البرامج التدريبية المقدمة لأعضاء هيئة التدريس في الجامعات من تحديد الاحتياجات الندريبية لهم وأن يراعى إعادة تقييم تلكك الاحتياجات وفق مستجدات

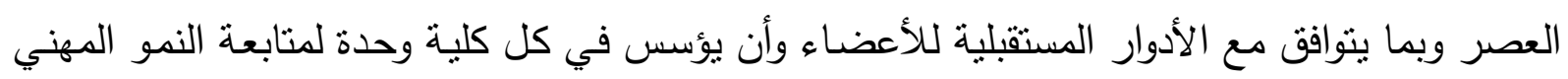
لهم في ضوء خطة لتتمية مهاراتهم على مسنوى المؤسسة والمستوى الفردي.

السؤال الفرعي الرابع:- "ما مستوى الرضا لاى أعضاء هيئة التتريس تجاه البرامج التدريبية " ؟ للتعرف على مستوى الرضا لدى أعضاء هيئة التدريس تجاه البرامج التنريبية تم حساب التكرارات والنسب المئوية والمتوسطات الحسابية والانحرافات المعيارية والرتب لاستجابات مفردات عينة الدراسة على عبارات الدحور وجاءت النتائج كما يوضحها الجدول الثالي:

جدول رقم (T 1) استجابات مفردات عينة الدراسة على عبارات محور مستوى الرضا لاى أعضاء هيئة التدريس تجاه البرامج التدريبية مرتبة تنازلياً حسب متوسطات الموافقة

\begin{tabular}{|c|c|c|c|c|c|c|c|c|}
\hline \multirow[b]{2}{*}{ 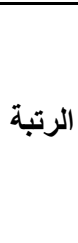 } & \multirow[b]{2}{*}{ 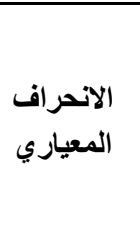 } & \multirow[b]{2}{*}{ المستوسط } & \multicolumn{3}{|c|}{ درجة الموافقة } & \multirow{2}{*}{ التكرار } & \multirow[b]{2}{*}{ 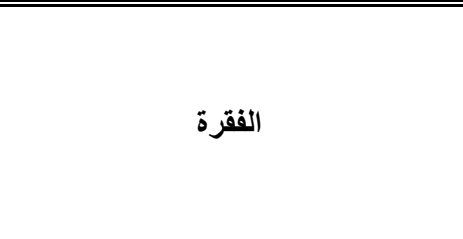 } & \multirow[b]{2}{*}{ p } \\
\hline & & & غوافق & إلى حو حـ & 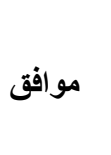 & & & \\
\hline \multirow[t]{2}{*}{1} & $.07 \mathrm{~V}$ & T.07 & T & r) & $\Gamma \varepsilon$ & s & \multirow{2}{*}{ 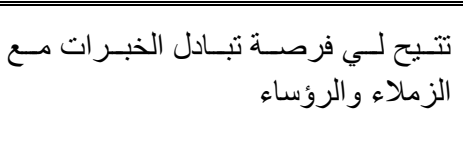 } & \multirow[t]{2}{*}{$\mu_{\Lambda}$} \\
\hline & & & r. 0 & ז4.人 & 09.7 & $\%$ & & \\
\hline$r$ & .041 & T.0r & 1 & ro & ru & ك & تســاعدني علـى تحسـين نو عيــة العــلـ & $\varepsilon r$ \\
\hline
\end{tabular}




\begin{tabular}{|c|c|c|c|c|c|c|c|c|}
\hline & & & 1.1 & $\leqslant r .9$ & $0 \leqslant . \varepsilon$ & $\%$ & وجودته & \\
\hline \multirow[t]{2}{*}{$r$} & .079 & T. ET & r & TV & rA & ك5 & \multirow{2}{*}{ تتيح لي فرصـة للنمو و اكتسـاب مهار ات } & \multirow{2}{*}{ rv } \\
\hline & & & r.o & $\leqslant V . \varepsilon$ & $\leq 9.1$ & $\%$ & & \\
\hline \multirow{2}{*}{$\varepsilon$} & .717 & T.MV & $\varepsilon$ & $r \wedge$ & ro & ك & \multirow{2}{*}{ تالتدريبية في العملية التعليمية توظتية محى البر امج } & \multirow{2}{*}{$\varepsilon$. } \\
\hline & & & $\mathrm{V}$. & $\leq 9.1$ & $\varepsilon r . q$ & $\%$ & & \\
\hline \multirow{2}{*}{0} & $\because 7 \leq 0$ & T.TV & 0 & rY & rY & ك5 & \multirow{2}{*}{ نقاط القوة و الضعنى تقيبم آدائي ذاتياً و اكتشـاف } & \multirow{2}{*}{$\leqslant 1$} \\
\hline & & & $\wedge . \wedge$ & $\{0.7$ & $\leq 0.7$ & $\%$ & & \\
\hline \multirow{2}{*}{7} & $.7 \leq 0$ & T.r.V & 0 & $\overline{r T}$ & ry & ك & \multirow{2}{*}{ 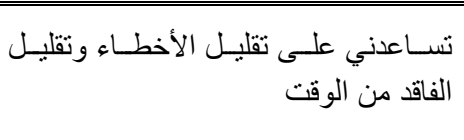 } & \multirow{2}{*}{$\varepsilon r$} \\
\hline & & & $\wedge . \wedge$ & $\leq 0.7$ & $\{0.7$ & $\%$ & & \\
\hline \multirow{2}{*}{ v } & $.71 \pi$ & T.YT & 0 & rr & $r$. & 5] & \multirow{2}{*}{ 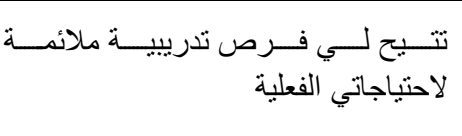 } & \multirow{2}{*}{ דr } \\
\hline & & & $\wedge . \wedge$ & 07.1 & ro.1 & $\%$ & & \\
\hline \multirow{2}{*}{$\wedge$} & $\because V r q$ & T.YO & 1. & rT & TS & 5 & \multirow{2}{*}{ جديد في مجال تخص الإطلاع على كل مـا هو } & \multirow{2}{*}{ rq } \\
\hline & & & $1 V .0$ & $\varepsilon \cdot . \varepsilon$ & $\leq r_{.} 1$ & $\%$ & & \\
\hline \multirow{2}{*}{9} & $.77 V$ & T.19 & 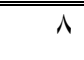 & $r$. & 19 & 5) & \multirow{2}{*}{ و ومسؤلياتي تجاه وأكثر قدرة على القيام بو اجباتي } & \multirow{2}{*}{$\leqslant 0$} \\
\hline & & & $1 \leqslant$. & or. 7 & r.r. & $\%$ & & \\
\hline \multirow{2}{*}{1.} & .794 & T.IS & 1. & 19 & 11 & ك] & \multirow{2}{*}{ واعاتنجي على تغيير الكثير من المواقف } & \multirow{2}{*}{$\leqslant \varepsilon$} \\
\hline & & & IV.0 & 0.9 & TI.7 & $\%$ & & \\
\hline & .0 .1 & T.To & \multicolumn{6}{|c|}{ المتوسط العام } \\
\hline
\end{tabular}

يشير الجدول السابق إلى أن أبرز ملامح الرضا لدى أعضاء هيئة التدربس تجاه البرامج التدربيية تتمثل في أتاحتها لهم فرصة تبادل الخبرات مع الزملاء والرؤسـاء وتحسين نوعية العمل وجودته وإتاحة الفرصـة للنمو واكتساب مهارات مهنية جديدة و توظيف محتوى البرامج التدربيية في العملية التعليمية ، وهذا يؤكد على أهميـة التواصل فيمـا بينهم مما يتيح لهم تبادل المعارف والخبرات الأمر الذي يحقق الفائدة لهم ويساعد على زيادة وتطور نموهم المهني ويعزز من رضاهم عن البرامج التدريبية ،وتتفق هذه النتائج مع نتيجة دراسة ( السديري وآخرون ،2012)التي أظهرت نتائجها وجود استفادة مرتفعة لدى أعضاء هيئة التدريس من البرامج التدريبية المقدمة من عمادة تطوير المهارات في مجالات التخطيط للتدريس والتتفيذ والتقويم واستخدام التقنيـة ، وأن جميع البرامج تعتبر ذات درجة فاعليـة مرتفعة من وجهة نظرهم،وكذلك دراسة ( محمد وآخرون،2015) التي أظهرت أن درجة فاعلية البرامج التدربيية المقدمة من عمادة الجودة 
والتطوير بجامعة حائل تقع ضمن درجة القبول والرضا في كل مجال من مجالات التدريب ، وأيضاً دراسة (Coffy , Gibbs , 2000 ) في تحسين مهاراتهم التنريسية والبحثية وفي التعامل مـع الطلاب ، ودراسـة ( الثربيني ،2004) والتي بينت أهمية إنثاء مركز لتتمية وتطوير أعضاء هيئة التدريس وإقامة دورات لهم للتعرف على الأساليب الحديثة في الندريس والبحث وأن هذه الآليات سنساهم في الارتقاء بالمستوى النوعي لهم وتجعلهم بسايروا الاتجاهـات التربويـة الحديثة مهـا ينعكس بصورة إيجابيـة على مخرجـات المؤسسـة التعليميـة ،و دراسـة

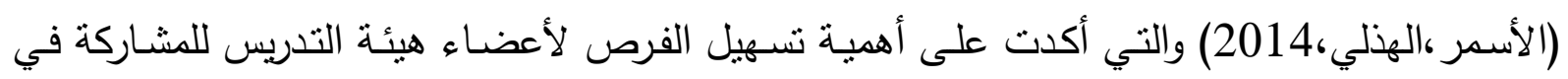

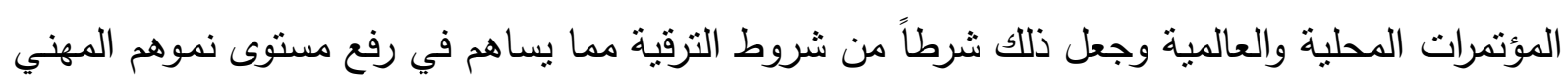

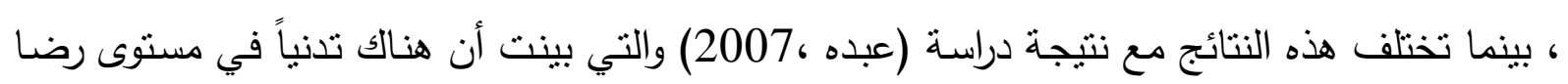
أعضاء هيئة التدريس من حيث عدم توافر فرص اكتساب مهارات جديدة في العمل من خلال البرامج التدريبية والمشاركة في المؤتمرات والندوات العلمية المحلية والخارجية.

السؤال الرئيس الثاني :- "ما المقترحات لزيادة فاعلية البرامج التدريبية لأعضاء هيئة التدريس " ؟ للتعرف على المقترحات لزيادة فاعلية البرادج التدريبية لأعضاء هيئة التدريس تم حساب التكرارات والنسب المئوية والمتوسطات الحسابية والانحرافات المعيارية والرتب لاستجابات مفردات عينة الدراسة على عبارات الدحور وجاءت النتائج كما يوضحها الجدول الثالي: جدول رقم (؛ 1) استجابات مفردات عينة الدراسة على عبارات محور المقترحات لزيادة فاعلية البرامج

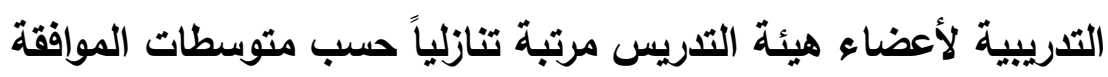

\begin{tabular}{|c|c|c|c|c|c|c|c|c|}
\hline \multirow[b]{2}{*}{ 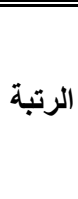 } & \multirow{2}{*}{ الالاحياري } & \multirow{2}{*}{ الحسابي } & \multicolumn{3}{|c|}{ لدرجة الموافقة } & \multirow{2}{*}{ التكرار } & \multirow[b]{2}{*}{ 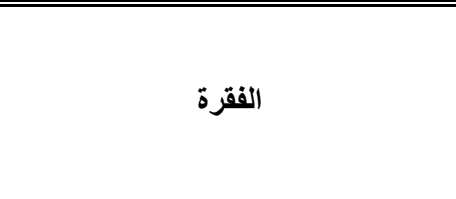 } & \multirow[b]{2}{*}{ p } \\
\hline & & & غو غير & حو مافق إلى & موافق - & & & \\
\hline \multirow[t]{2}{*}{1} & \multirow[t]{2}{*}{..$\Upsilon 100$} & \multirow[t]{2}{*}{ T.91 } & - & 0 & or & (5) & \multirow{2}{*}{ أهندربية متابعة أثر البر امج التدرييية على } & \multirow[t]{2}{*}{00} \\
\hline & & & - & $\Lambda . \Lambda$ & $91 . r$ & $\%$ & & \\
\hline \multirow[t]{2}{*}{ r } & \multirow[t]{2}{*}{ 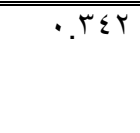 } & \multirow[t]{2}{*}{ r.91 } & 1 & $\bar{T}$ & or & s & \multirow{2}{*}{ منعاً للعشو أنتئية والتكرار المسبق للبرامج التنريبية } & \multirow{2}{*}{$\leqslant \wedge$} \\
\hline & & & 1.1 & $0 . r$ & 94. & $\%$ & & \\
\hline$r$ & . हYT & 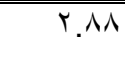 & $\bar{r}$ & $\Gamma$ & Or & ك5 & إخضــــاع البــر امج التدريبيـــة لعمليــات & 01 \\
\hline
\end{tabular}




\begin{tabular}{|c|c|c|c|c|c|c|c|c|}
\hline & & & r.o & $0 . \mu$ & $91 . r$ & $\%$ & التقويم و التطوير المستمرة & \\
\hline \multirow[t]{2}{*}{$\varepsilon$} & .100 & T.AT & - & $\Lambda$ & $\leqslant 9$ & 5 & \multirow{2}{*}{ أهمية التركيز على الاحتياجـات التدرييية } & \multirow[t]{2}{*}{$\leqslant V$} \\
\hline & & & - & $1 \varepsilon$. & ᄉ५. & $\%$ & & \\
\hline \multirow{2}{*}{$\circ$} & $\because \leqslant \leqslant 1$ & T.AT & r & $\varepsilon$ & 01 & ك & \multirow{2}{*}{ والهمية تزويد القاعات بأحدث التجهيزات } & \multirow{2}{*}{ or } \\
\hline & & & r.o & v. & 19.0 & $\%$ & & \\
\hline \multirow{2}{*}{7} & 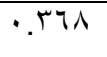 & $Y . \wedge \varepsilon$ & - & 9 & $\varepsilon \wedge$ & 5 & \multirow{2}{*}{ والهيـة التمييز بين الاحتياجـات التدرييـية } & \multirow{2}{*}{$\leqslant 7$} \\
\hline & & & - & 10.1 & $\Lambda \Sigma . Y$ & $\%$ & & \\
\hline \multirow{2}{*}{ 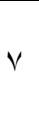 } & $\because \leqslant 1 \leqslant$ & T.A乏 & 1 & V & $\sum 9$ & 5 & \multirow{2}{*}{ المتخص إسناد عملية تحديد الاحتياجـات لغير } & \multirow{2}{*}{$\leqslant 9$} \\
\hline & & & 1.1 & Ir.r & ᄉ५. & $\%$ & & \\
\hline \multirow{2}{*}{$\wedge$} & $\because \leq 1 \leq$ & 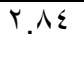 & 1 & V & $\leqslant 9$ & ك & \multirow{2}{*}{ ألاحية إثرات الت المتدربين في عملية تحديد } & \multirow{2}{*}{$0 \leqslant$} \\
\hline & & & 1.1 & Ir.r & ᄉ५. & $\%$ & & \\
\hline \multirow{2}{*}{9} & $\because \leqslant \leqslant 1$ & $r . \wedge 1$ & 1 & 9 & $\varepsilon V$ & 5 & \multirow{2}{*}{ بصفة دورية الاحتقاجات التدريبية للمتدربين } & \multirow{2}{*}{ or } \\
\hline & & & $1 . \wedge$ & 10.1 & Ar.o & $\%$ & & \\
\hline \multirow{2}{*}{$1 \cdot$} & $.0 Y 7$ & T.Vq & $r$ & 7 & $\varepsilon \lambda$ & ك5 & \multirow{2}{*}{ 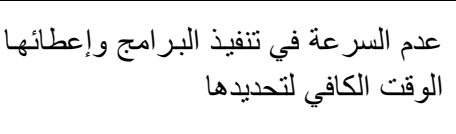 } & \multirow{2}{*}{0.} \\
\hline & & & $0 . r$ & $1 \cdot .0$ & $\Lambda \varepsilon . Y$ & $\%$ & & \\
\hline & .910 & r.Ao & \multicolumn{6}{|c|}{ المتوسط العام } \\
\hline
\end{tabular}

يشير الجدول السابق إلى أن أبرز المقترحات لزيادة فاعلية البرامج التدريبية لأعضاء هيئة التدريس تتمثل في متابعة أثر البرامج التدريبية على المتدربين والتخطيط المسبق للبرامج وإخضـاعها لعمليات التقويم والتطوير المستمرة والتركيز على الاحتياجـات الحاليـة والمستقبلية وتزويد القاعـات بأحدث التجهيزات

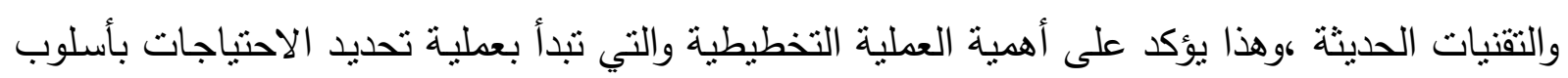

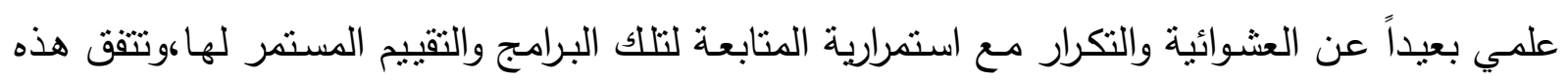
النتائج مع نتيجة دراسة(عبد الوهاب ، عثمان ،2014) التي أكدت على أن التدريب وتحديد الاحتياجات

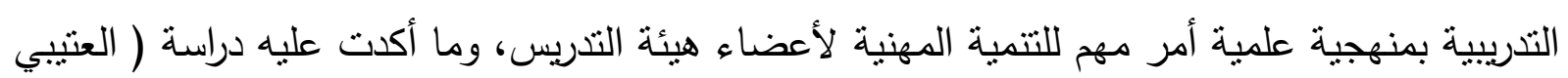

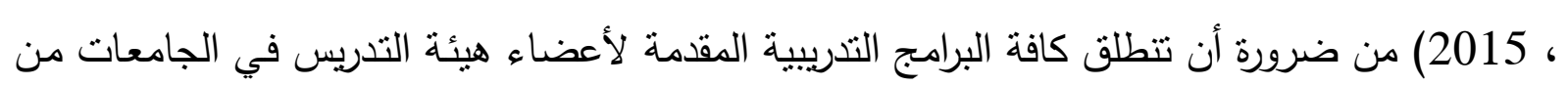

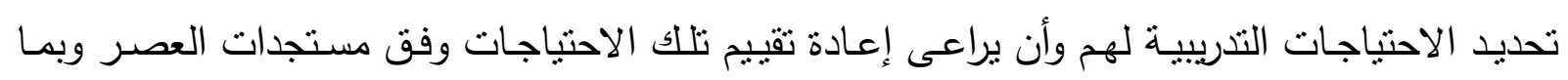


يتوافق مع الأدوار المستقبلية للأعضاء وأن يؤسس في كل كلية وحدة لمتابعة النمو المهني لهم في ضوء خطة لتتمية مهاراتهم على مستوى المؤسسة والمستوى الفردي، كما تتفق مع نتيجة دراسة ( علي ،2005) والتي بينت أنه لابد من وجود سياسـة مكتوبـة لتدريبهم مـع تحفيزهم على الالتحاق بالدورات التدريبية وتخصيص ميزانية للتدريب ووضع خطة شاملة للتدريب، و دراسة ( العمري ، 2011) التي بينت أن أهم مقترحات الأعضاء حول التدريب المناسب الذي يرغبون في الحصول عليه هو ربط التدريب بالحاجات

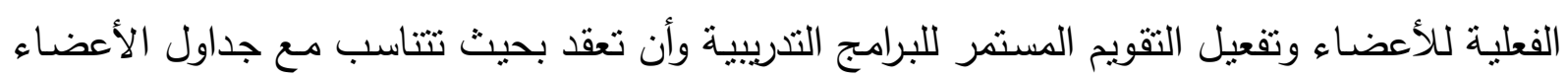

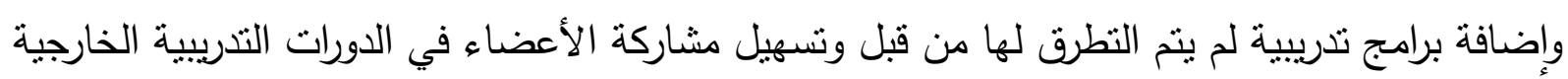
على المستوى الإقليمي والعالمي كما تتفق مع نتيجة دراسـة (شملق ،2013 ) والني بينت أهمية تقييم البرامج التدريبية من خلال قياس الأثر بعد التدريب والتركيز على التطبيقات العملية بالإضافة إلى الجانب النظري والاعتماد على وسائل التكنولوجيا الحديثة وضرورة إثراك أعضاء هيئة التدريس من المتخصصين في المناهج وطرائق التدريس والقياس والتقويم في إعداد وتطوير البرامج التنريبية للاستفادة من خبراتهم في هذا المجال ، وأيضـاً دراسـة ( عثـان ،2015) التي أكدت على ضـرورة الاهتمـام بالاحتياجـات التدريبية وإعادة النظر في البرامج التدريبية من خلال إخضاعها لعمليات التقويم والتطوير المستمرة. : نتائج الدراسة : n

- مفردات عينة الدراسة موافقات على مدى قدرة البرامج التنريبية على تلبية احتياجات أعضاء هيئة التدريس ، أبرزها تتمنل في إتاحة الفرصة للمشاركة في تقويم البرامج التنريبية وتسهيل إجراءات الالتحاق بها و توفير الحقائب التدريبية و الاهتمام بالقاعات التدرييية وتجهيزها بالتقنيات الحديثة و توفر الوسائل والأجهزة والتأكد من سلامتها وكفاءتها.

- مفردات عينة الدراسة موافقات على الإجراءات والأساليب المنبعة في تحديد الاحتباجات التدريبية ،أبرزها

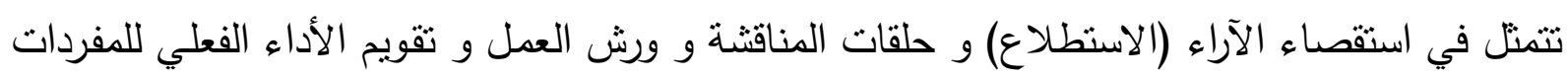

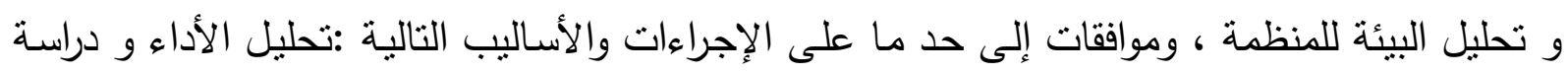
السجلات والتقارير و الملاحظة و تحليل المهام و الوثائق.

- مفردات عينة الدراسة موافقات على المعوقات التي تحد من فاعلية البرامج التدريبية في تحقيق أهدافها وكانت أبرزها كثرة الأعباء المكلف بها عضو هيئة التدريس و السرعة في تتفيذ البرامج التدريبية و التركيز

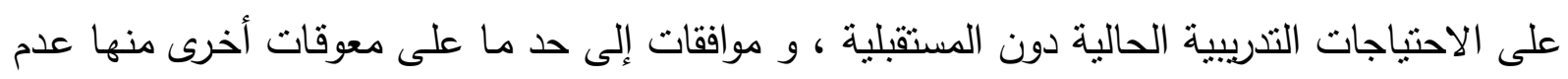




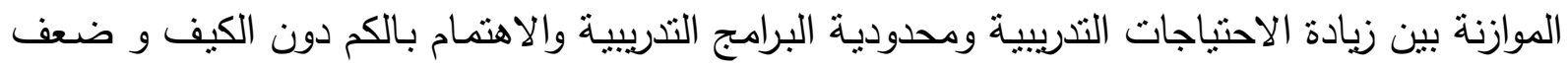

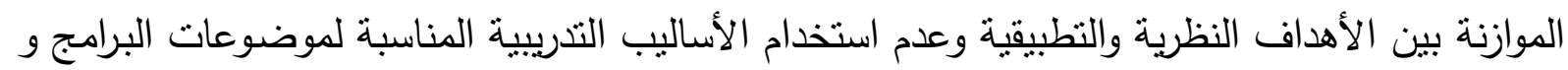
ضعف الموازنة بين الموضوعات ومدتها ، و غير موافقات على صعوبة التسجيل في البرامج التنريبية . -مفردات عينة الدراسة موافقات على عدد من ملامح الرضـا تجاه البرامج التدريبية كإتاحة فرص تبادل الخبرات مع الزملاء والرؤساء وفرص للنمو واكتساب مهارات مهنية جديدة و تحسين نوعية العمل وجودته

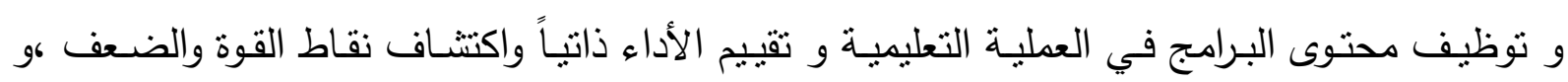
موافقات إلى حد ما على عدد من ملامح الرضا وهي إتاحة فرص تدريبية ملائمة للاحتياجات الفعلية و توفير فرص الإطـلاع على كل مـا هو جديد في مجـال التخصص و القدرة على القيـام بالواجبات والمسؤوليات تجاه الوظيفة و تغيير الكثير من المواقف والاتجاهات السلبية تجاه العمل.

- مفردات عينة الدراسة موافقات على عدد من المقترحات لزيادة فاعلية البرامج التدريبية لأعضاء هيئة

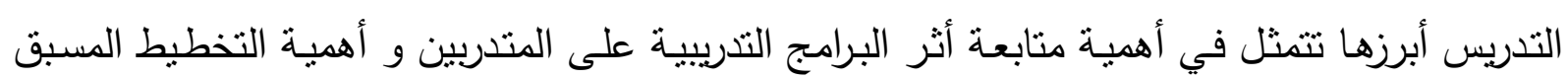

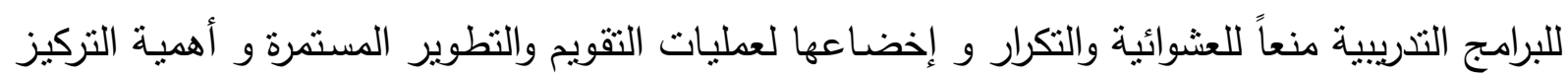

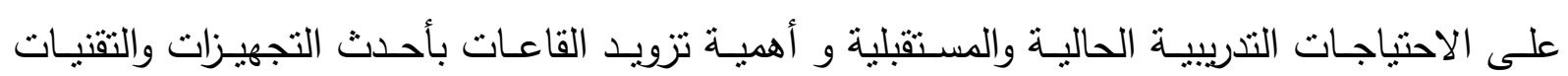
الحديثة.

\section{مقترحات الدراسة :}

-تتجيع أعضاء هيئة التنريس على تحقيق النمو العلمي والمهني من خلال ترغيبهم في حضور اللقاءات

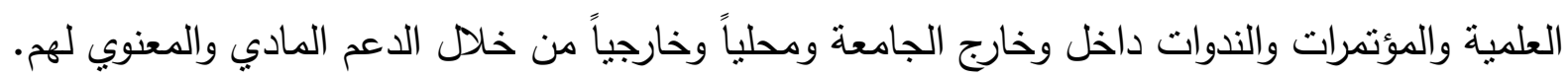
- أهمية إجراء دراسات وبحوث بشكل دوري لتحديد الاحتياجات التدريبية الفعلية لتكون منطلقاً لنطوير

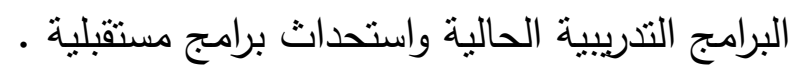
- توجيه نظر القائمين على وضع البرامج التدريبية إلى ضرورة التعرف على الاحتياجات الفعلية لأعضاء

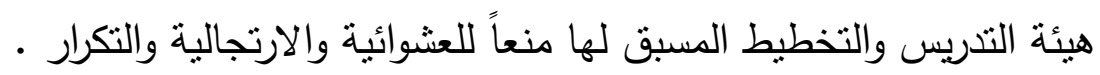

- تفعيل نظام التدريب عن بعد حتى تصل الخدمات التدريبية لأماكن عمل أعضاء هيئة التدريس لضمان

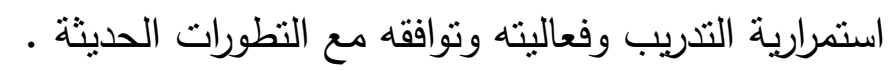

- إجراء دراسات لقياس الرضا الوظيفي والروح المعنوية لأعضاء هيئة التدريس في الجامعة . 
-أهمية التركيز على التطبيقات العملية إضـافة إلى الجانب النظري بالاعتماد على وسـائل التكنولوجيا

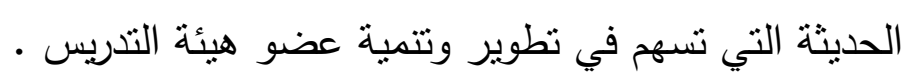
-أهميـة تكرار بعض البرامج التدريبية لأهميتها لأعضاء هيئة التدريس حتى ينسنى للجميع حضورها

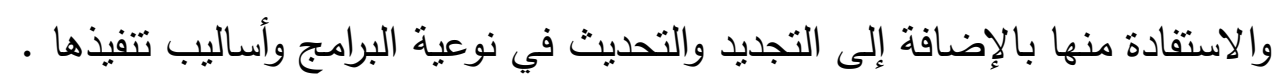
- أهمية النظر في تخفيف العبء التدريسي وزيادة البدلات واستحداث بدلات جديدة متعلقة بالتدريب . -أهميـة عملية المتابعـة مـن خـلال إجراء مسوح واستطلاع لمعرفة المعوقات التي تحول دون استفادة

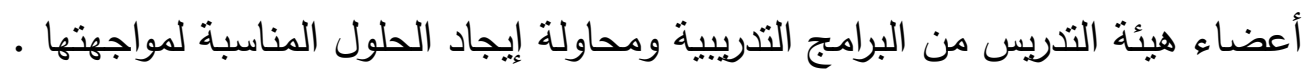
-أهمية الاستفادة من خبرات أعضاء هيئة التدريس من المتخصصين في مناهج وطرق التدريس والقياس والتقويم في إعداد وتطوير البرامج التدريبية . -اتباع أساليب تقويم مناسبة للبرامج التدريبية كقياس الأثر بعد التدريب . -أهمية تحسين طرق ووسائل التدريب مع التركيز على تحديث المادة العلمية للبرامج التدريبية . - توفير الامكانيات والمصادر اللازمة للبرامج التدريبية وإعطاءها الوقت الكافي والمناسب لها. 


\section{المراجع : \\ أولاً : المراجع العربية}

- إبراهيم ، محمد (2003) منظومة تكوين المعلم في ضوء معايير الجودة الثاملة ، دار الفكر ، الأردن .

-الأسمر، منى ، الهذلي ، سهى (2014) مدى تمكين أعضاء هيئة التدريس بالجامعات السعودية من وجهة نظرهم

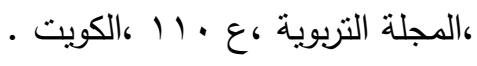

-ابن موسى ، علي بن عبد اله ( V. . . ) ، العلاقة بين الأداء المهني عند أعضاء هيئة التدريس وارتفاع مستوى التحصيل عند الطلاب في كلية التربية بجامعة الملك خالد ، المجلة العربية للتربية ، تونس . -أبو النصر ،مدحت (2004) إدارة الجمعيات الأهلية في مجال رعاية وتأهيل ذوي الاحتباجات الخاصة ، مجموعة النيل العربية ، القاهرة .

- آل فرحان، محمد (2012)الاحتياجات التدريبية لأعضاء هيئة التدريس بكلية التربية بجامعة أم القرى ، رسالة ماجستير ، كلية التربية ، جامعة أم القرى كمكة المكرمة. - بدوي ، أحمد ( 997 (1) معجم المصطلحات الاجتماعية ، مكتبة لبنان ، بيروت . - البردي ، عبدالعزيز (2008) الاحتباجات التدريبية في مجال التقنيات التربوية للمشرفين التربوبين بمحافظة الطائف التعليمية بالمملكة العربية السعودية ، رسالة دكتوراه ،كلية التربية،جامعة أم القرى ، مكة المكرمة . - بطاينه، محمد (2003)أسس تحديد الاحتباجات التدريبية لثركة الاتصالات الأردنية ، رسالة ماجستير ، كلية الاقتصاد والعلوم الإدارية ، جامعة اليرموك ، الأردن •

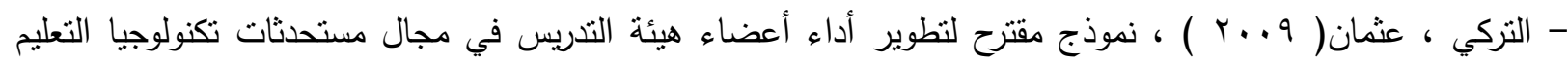
والمعلومات في ضوء احتياجاتهم التدريبية بكلية المعلمين - جامعة الملك سعود ، مجلة دراسات في المناهج وطرق التدريس

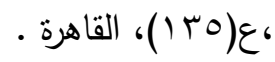
-الجبوري ، حامد (2005) نظم التعليم والتدريب في الجامعات روية استراتيجية ومستقبلية ، الملتقى العربي الثاني للتربية والتعليم ، مؤسسة الفكر العربي ومكتب التربية العربي لدول الخليج ، بيروت . - الحدابي ،داوود و الهمداني ، رجاء ( 2010) مدى تتفيذ أعضاء هيئة التدريس بجامعة صنعاء لمهامهم ، المجلة العربية لضمان جودة التعليم العالي ، العدد 7 ، مركز تطوير التعليم الجامعي ، جامعة صنعاء ، اليمن •

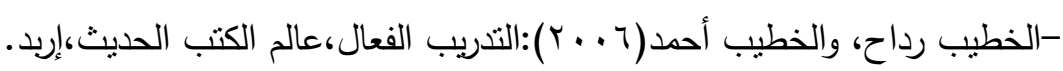
-خليل ، نبيل سعد (2013) التدريب أثناء الخدمة ، جامعة سوهاج ، كلية التربية ، مصر . -داوود ، أمان (2014) مستوى الفاعلية التربوية لبرنامج تأهيل معلمي المرحلة الأساسية الدنيا أنثاء الخدمة من وجهة نظرهم وعلاقته باتجاهاتهم نحو مهنة التدريس ، رسالة ماجستير ، جامعة النجاح الوطنية ، فلسطين • -السديري ،أحمد وآخرون (2012) أثز البرامج التدريبية على الأداء التدريسي لأعضاء هيئة التدريس بجامعة الملك سعود

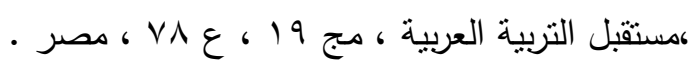


-السراج،رجب (2010) واقع عملية تحديد الاحتياجات التدريبية للعاملين في المنظمات غير الحكومية بقطاع غزة ، رسالة ماجستير ، جامعة الأزهر ، غزة. سكر ، أحدد (2013) دور أعضاء هيئة التدريس في كليات الإعلام ونظيراتها بالجامعات الفلسطينية في تعزيز نقافة الحوار لدى طلبتهم وسبل تطويره ، رسالة ماجسنير ، كلية التربية ، جامعة الأزهر ، غزة . سناني ، عبد الناصر (2012) الصعوبات التي يواجهها الاستاذ الجامعي المبتدئ في السنوات الأولى من مسيرته المهنية ، رسالة دكتوراه ،جامعة باجي مختار ، كلية الآداب والعلوم الانسانية والاجتماعية ، الجزائر • -السيد ، هدى ، مصطفى ، حلمي (2002) الاحتياجات التدريبية لرؤساء مجالس الأقسام الأكاديمية بالجامعات المصرية، الجمعية المصرية للتربية المقارنة والإدارة التعليمية ، كلية التربية ، جامعة عين شمس ، ع V ، القاهرة . - شاهين ، محمد (2004) التطوير المهني لأعضاء الهيئات التدريسية كمدل لتحقيق جودة النوعية في التعليم الجامعي ، ورقة علمية في مؤتمر النوعية في التعليم الجامعي الفلسطيني ، جامعة القدس المفتوحة ، رام الله . -الشربيني ، غادة (2004)ثقيم أداء المعلم الجامعي في ضوء مؤسسات التعليم العالي بالمملكة العربية السعودية ، ندوة تتمية أعضاء هيئة التدريس في مؤسسات التعليم العالي ، جامعة الملك سعود ، الرياض . -الثخشير ، حلا محمود (2010) مستوى التتمية المهنية لدى أعضاء الهيئة التدريسية في جامعة النجاح الوطنية من وجهة نظرهم ، رسالة ماجستير ، جامعة النجاح الوطنية ، كلية الدراسات العليا ، فلسطين • -شملق، عبدالمنعم (2013) مستوى فاعلية البرنامج التدريبي لمعلمي الرياضيات للصفوف (ع-9) في تتمية كفاياتهم التعليمية من وجهة نظرهم والمدربين ، رسالة ماجستير ، كلية التربية ، جامعة عدن ، اليمن • - صائغ ، عبدالرحمن (2005) النموذج العشري لنطوير مؤسسات التعليم العالي في البلدان العربية ، الملتقى العربي الثاني للتربية والتعليم ، مؤسسة الفكر العربي ومكتب التربية العربي لدول الخليج ، بيروت . -الصيرفي ،محمد (2009) التنريب الإداري : تحديد الاحتياجات التدريبية وتصميم البرامج التدريبية ، دار المناهج للنشر والتوزيع ، عمان • -الطراونه كتحسين (2011 ) تحديد الاحتباجات التدريبية كأساس لعملية التخطيط للتدريب في الاجهزة الأمنية ،ندوة الأساليب الحديثة في التخطيط والتدريب ، جامعة نايف العربية للعلوم الأمنية ، الرياض .

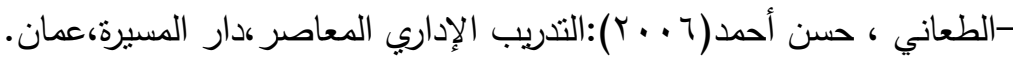
-العامري ، عبدالعزيز (2014) المشكلات التي تواجه أعضاء هيئة التدريس في كليات التربية بالجامعات اليمنية من وجهة

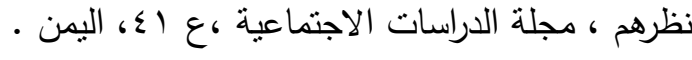
-العبادي وآخرون ، هاشم (2006) إدارة الموارد البشرية مدخل استراتيجي متكامل ، ط ا، الورق للنشر ، عمان • -عبد الغفار، نوره (2006) الاحتياجات التدريبية لأعضاء هيئة التدريس بكليات التربية للبنات للقبام بمهام تصميم الدقرر الدراسي والإعداد لتنفيذه ، مجلة جامعة طيبة ، العلوم التربوية ، ع ع ، المدينة المنورة . -عبدالوهاب، فيصل، عثمان،حسن (2014 )احتياجات أعضاء هيئة التدريس التدريبية في كليات التربية بجامعات السودان ، جامعة العلوم والتكنولوجيا ، المجلة العربية لضمان جودة التعليم الجامعي ، اليمن • 
- عبده ،هيكل طه (2007) قباس عوامل الرضا الوظيفي لأعضاء الهيئة التدريسية ومساعديهم في الجامعات اليمنية وأثره في متحصلات العملية التعليمية ، رسالة ماجستير ، جامعة عدن ، اليمن ·

-العتيبي ، سارة (2015) الاحتياجات التدريبية لأعضاء هيئة التدريس في ضوء مهارات التدريس الفعال بكلية العلوم ،جامعة الأميرة نورة بنت عبدالرحمن ، المجلة التربوية الدولية المتخصصة ، مج ع ، ع 7، الأردن • -عثمان ، عبير ( 2015) الاحتياجات التدريبية لمعلمي الملابس الجاهزة من منظور منظومة ضمان الجودة والاعتماد ،

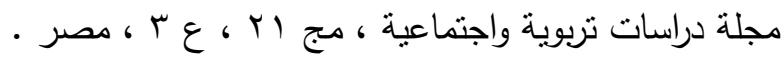

-علي ، علي (2005) : تتمية وتطوير كفايات وفعالية أعضاء هيئة التنريس بمؤسسات التعليم العالي، الملتقى العربي الثاني للتربية والتعليم ، مؤسسة الفكر العربي ومكتب التربية العربي لدول الخليج ، بيروت . -العمري ، أسماء (2010) الحاجات التدريبية لأعضاء هيئة التدريس بجامعة الإمام محمد بن سعود الإسلامية ، رسالة ماجستير ، كلية العلوم الاجتماعية ، جامعة الإمام محمد بن سعود الإسلامية ، الرياض

- غالب ، ردمان و عالم ، توفيق (2008 ) التتمية المهنية لأعضاء هيئة التدريس مدخل للجودة الثشاملة في التعليم الجامعي ، المجلة العربية لضمان جودة التعليم الجامعي ، العدد ا ،جامعة صنعاء ، اليمن • -الكبيسي ،عبدالواحد(2011) واقع جودة التدريس الجامعي وسبل الارتقاء به ، المؤتمر العربي الدولي لجودة التعليم العالي ، جامعة الزرقاء الخاصة ، عمان · منان -الكفافي،محمد جمال(V · . †):الاستثمار في الموارد البشرية للمنافسة العالمية،الدار الثقافية،القاهرة. - ماتير كبربارا (2000) الأساليب الإبداعية في التدريس الجامعي ، دار الثروق للنشر والتوزيع، الأردن • -محمد ، هيثم وآخرون(2015) دراسة تقييمية لأثر البرامج التدريبية في عمادة الجودة والتطوير بجامعة حائل ، جامعة حائل

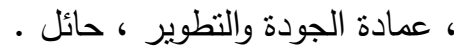

-مدني، غازي بن عبيد(2002): تطوير التعليم العالي كأحد روافد النتمية البشرية في المملكة العربية السعودية، ورقة عمل مقدمة

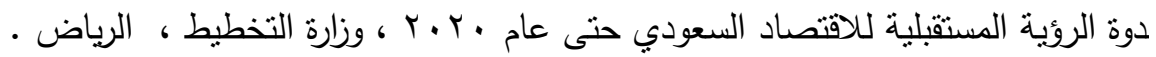

-مرسي ، محمد منير (2002): الاتجاهات الحديثة في التعليم الجامعي المعاصر و أساليب تدريسية، عالم الكتب ، القاهرة . -المخلافي، محمد سرحان خالد(2002): بناء أداة لتقييم كفاءة الأداء التدريسي لعضو هيئة التدريس الجامعي في جامعة صنعاء، مجلة البحوث و الدراسات التربوية، العدد 71 ا، مركز البحوث و التطوير التربوي، اليمن • -المهيري ، سعيد ، و أبو عالي ، سعيد (2005( التتمية المهنية المستدامة لأعضاء هيئة التدريس ، الملتقى العربي الثاني للتربية والتعليم ، مؤسسة الفكر العربي ومكتب التربية العربي لدول الخليج ، بيروت . 


\section{ثنانياً : المراجـع الأجنبية:}

- Kdlinski, Johon, (2002), Evaluation of Success and Failure Factors and Criteria in Implementation of Total Quality Management Principles in Administration at Selected Institution of Higher.

- Barbara Thomlison (2001) Desriptive Studies In Bruce A .Thyer : The Hand Book Of Social Work Research Methods (London: Sage Publication, In.

- Willmer,pat (2003),student feedback and evaluation of teaching policy/procedural document, final version, teaching learning and assessment committee, university of st Andrews, united kingdom .

- Catherine Soanes \& Angus Stevenson (2005) Ned Oxford dictionary of English, New York, Oxford University Press .

- Coffy , M , Gibbs , G (2000) Can Academics benefit from Training ? Some Preliminary evidence, Teaching in Higher Education , 3 (5) .

- Akullu,E,B, Opolot - Okurut, C . and Ssentamu , P.N(2014).Addressing Pedagogical Training Needs of Teaching Staff : Lessons From Makerere University Short Professional Development Programs 2006 - 2010 . American Journal of Educational Research ,2 (12).

- Mountjoy ,Mc .(2006) Faculty Perceptions of Empowerment in Three Private Fouryear Colleges.Published doctoral dissertation , University of Missouri- Colubia UMI NO 3013005.

- Jordan, Sue(2000) Educational Input and Patient Outcomes : Exploring the Gap Methodological Issues in Nursing Research , 31 , (2).

- John Baulmetis \& Phyllis Dutwin (2000) The ABC OF Evaluation, California, Jessey Bass, Inc , Publishers. 